\title{
İslami Finans Okuryazarlığı ve Finansal Tercihlere Etkisi
}

\author{
Merve Büşra Altundere Doğan*
}

Öz

Finans sektörü, son dönemde gösterdiği hızlı gelişme ve büyümeyle birlikte modern ekonomik hayatın önemli bir parçası haline gelmiştir. İslam coğrafyasında bu değişime paralel olarak, İslami finansın da gelişerek finansal sistem içinde kayda değer bir yer edindiği açıkça görülmektedir. Bu araştırma, Türkiye'deki İslami finans okuryazarlığını üniversite öğrencileri bağlamında inceleyerek İslami finans sisteminin yaygınlaşması bakımından katkılarını analiz etmiştir. Anket çalışması yapılarak öğrencilerin İslami finans okuryazarlık düzeyi ölçülmüş ve bu düzeyi etkileyen faktörler ile finansal okuryazarlıkla ilişkisi doğrusal regresyon yöntemiyle araştırılmıştır. Ayrıca, ikili lojistik regresyon analiziyle, İslami finans okuryazarlık düzeyindeki artışın öğrencilerin katılım bankacılığını tercih etmelerinde olumlu etkisi olacağı sonucuna varılmıştır.

Anahtar Kelimeler: Finansal okuryazarlık, islami finans okuryazarlığı, islami finans sistemi, Hanehalkı finansı.

JEL Sınıflandırması: D14, 120, C35, C31.

\section{Abstract - Islamic Financial Literacy and its Effect on Financial Choices}

Financial system has become a prevalent part of the modern economic life. In parallel to this, Islamic finance is also improving and standing out as an integral component of the financial system in the Islamic world. This study examines Islamic financial literacy and its contribution to the expansion of Islamic financial system in Turkey. In the light of a survey conducted among university students, this paper measures the Islamic financial literacy level; and analyzes its determinants together with its relation to the financial literacy through a linear regression method. Moreover, this paper, by conducting a binary logistic regression analysis, shows that a higher level of Islamic financial literacy leads to a higher probability of choosing Islamic banks.

Keywords: Financial literacy, Islamic financial literacy, Islamic financial system, Household finance.

JEL Classification: D14, 120, C35, C31.

\footnotetext{
* istanbul Sabahattin Zaim Üniversitesi, İşletme ve Yönetim Bilimleri Fakültesi, iktisat Bölümü - E-posta: merve.altundere@izu.edu.tr ORCID ID: https://orcid.org/0000-0002-5640-9310
}

Makale Gönderim: 22.01.2020

Makale Kabul: 28.05.2020

DOI: http://dx.doi.org/10.46520/bddkdergisi.789957 


\section{Giriş}

Dünya genelinde her geçen gün gelişerek daha da derinleşen finansal sistem hem ülkeler hem de bireyler için yeni imkânlar ve kazanımlar sunmaktadır. Bu değişim aynı zamanda, kimi ulusal kimi küresel boyutta finansal krizlere yol açabilmekte; böylece ülkelerin ekonomisinde ve bireylerin yaşamında ciddi ve tesirleri uzun süreli izler bırakabilmektedir. Bu nedenle, bireylerin güncel finans sistemi ve işleyişi hakkında bilgi sahibi olması; onların bütçelerini sağlıklı şekilde kullanabilme, birikimlerini daha iyi değerlendirebilme, yatırımlarında gerçekçi ve verimli davranabilme, ayrıca karşılaşılan finansal riskleri yönetebilme yetilerinin gelişmesi bakımından son derece faydalı ve gereklidir. Özellikle 2008 Küresel Finans Krizi sonrasında finansal okuryazarlık konusunun önemi bir kez daha ve küresel çapta ortaya çıkmıştır.

Son dönemde ülkeler ve uluslararası kuruluşlar tarafından bireylerin finansal okuryazarlık düzeyini ölçmek için birçok araştırma yapılmış ve bu araştırmalar sonucunda da düşük olduğu anlaşılan finansal okuryazarlık düzeyini artırmak amacıyla çeşitli finansal eğitim programları başlatılmıştır. Ekonomik Kalkınma ve İşbirliği Örgütü (OECD), uluslararası alanda yaptığı çok sayıda çalışmasıyla finansal okuryazarlık ve finansal eğitim konularındaki öncü kuruluşların başında gelmektedir (OECD/INFE, 2016). Türkiye'de de Türkiye Cumhuriyet Merkez Bankası (TCMB) finansal okuryazarlık konusuna odaklanarak araştırmalar yapmakta; her yaş grubuna uygun finansal okuryazarlık ve ekonomi eğitimi sağlamaktadır (TCMB, 2015; TCMB, 2019). Bunun dışında, Türkiye' de finansal okuryazarlık ile ilgili çalışmalar yapan başka kuruluşlar, banka ve dernekler de bulunmaktadır.

Finans sektörü genelinde yaşanan bu değişim ve gelişimin benzeri, İslam coğrafyasında İslami finans alanında da görülmektedir. İslami finans, bireylerin gelirini, harcamasını, birikim ve yatırımını İslami kurallara uygun olarak değerlendirebilmesine ortam hazırlar. Günümüzde, finans sistemi içerisinde İslami finans sektörünün de gelişerek yer edinmesiyle birlikte, İslami finans farkındalığı ve okuryazarlığı da önem kazanmaya başlamıştır.

İslami finans sistemi, İslam dininde haram olan faizli işlemleri kullanmadan faaliyetlerini gerçekleştirerek, özellikle dini hassasiyeti olanlara faizsiz finans alternatifleri sunmaktadır. Bu noktada, İslami şartlara uygun şekilde finansal sisteme dahil olmak isteyenlerin İslami finans konusunda bilinçlenmesinin ve İslami finans yöntemleri hakkında bilgi sahibi olmasının, yani İslami finans farkındalığı ve okuryazarlığı kazanmasının, İslami finans sistemine katılımlarında olumlu etkilerinin olacağı öngörülmektedir. 
Türkiye'de, güncel finans sistemi içinde henüz küçük bir paya sahip olan İslami finans, yeni yeni gelişmekte ve yaygınlaşmaktadır. Türkiye'deki ilk İslami finans kuruluşları kabul edilen "Özel finans kurumları" 1985 yılında faaliyetlerine başlamıştır. ${ }^{1}$ Bu kuruluşlar 2005'te "katılım bankası" adını alarak genel bankacılık sektörüne dâhil edilmiştir. Son yıllarda devletin de üç tane kamu katılım bankası kurmasıyla birlikte İslami finans alanındaki çalışmalar yeni bir ivme kazanmıştır. ${ }^{2}$ Bununla birlikte, son dönemde İslami sigorta şirketlerinin kurulması, özel sektör ve kamu kira sertifikası (sukuk) ihracına başlanması, faizsiz emeklilik şirketlerinin faaliyete geçmesi gibi gelişmeler İslami finans sisteminin banka dışı finansal kurumlarla da ilerleme kaydettiğini göstermektedir. Bütün bu gelişmelere rağmen, Türkiye' de katılım bankası dışındaki İslami finans kuruluşları sınılı sayıdadır (Özdemir ve Aslan, 2017). Ayrıca, katılım bankalarının bankacılık sektörü içerisindeki payı da hâlâ oldukça küçüktür. ${ }^{3}$

Bu araştırma, Türkiye'deki İslami finans okuryazarlık düzeyini üniversite öğrencileri bağlamında inceleyerek, bu düzeyin finansal okuryazarlıkla ilişkisini ve katılım bankacılığı vasıtasıyla İslami finans sektörünün yaygınlaşmasına katkısı olup olmayacağını analiz etmeyi amaçlamaktadır. Bu doğrultuda, üniversite öğrencilerine yönelik bir anket hazırlanarak İstanbul Sabahattin Zaim Üniversitesi'nin lisans öğrencilerine uygulanmıştır. Toplanan veriler, çoklu doğrusal regresyon ve ikili lojistik regresyon yöntemleri kullanılarak incelenmiştir.

Anket sonuçları, öğrencilerin İslami finans okuryazarlığının düşük düzeyde olduğunu ve öğrencilerin büyük bir kısmında İslami finans farkındalığının oluşmadığını göstermektedir. Doğrusal regresyon analizi yapıldığında, finansal okuryazarlığın İslami finans okuryazarlığına pozitif ve anlamlı olarak etki ettiği bulunmuştur. Ayrıca, öğrencinin cinsiyeti, öğrenim gördüğü fakültesi ve sınıfı, bankacılık sistemini kullanımı ve para konularına merakının da İslami finans okuryazarlık düzeyine etkisi olduğu anlaşılmıştır. Öte yandan, ikili lojistik regresyon analizleri sonucunda, İslami finans okuryazarlık düzeyindeki artışın öğrencilerin hem katılım bankaları tarafından kullanılan yöntemlerin İslam'a uygun olduğunu düşünmesini hem de banka hesabı açarken katılım bankalarını tercih etmesini olumlu yönde etkilediği görülmektedir.

İslami finans sisteminin gelişmesiyle birlikte İslami finans farkındalığı ve okuryazarlığı konusu da öne çıkmıştır. Buna rağmen, Türkiye'de ve dünyada, bu

1 Türkiye'de ilk İslami finans kuruluşları olarak Özel Finans Kurumları kabul edilmekle birlikte, 1975'te kamu tarafından kurulup 1978'e kadar faizsiz finans alanında faaliyetini sürdüren Devlet Sanayi İşçi ve Yatırım Bankası (DESiYAB) da İslami finans alanında bir başlangıç olarak değerlendirilebilmektedir (Özdemir ve Aslan, 2017).

2 Türkiye'de şu anda Albaraka Türk, Kuveyt Türk, Türkiye Finans, Ziraat Katııım, Vakıf Katılım ve Emlak Katılım olmak üzere altı tane katılım bankası bulunmaktadır (TKBB, 2019). Son üçü kamu katılım bankasıdır.

3 Türkiye Katıım Bankaları Birliği sonuçlarına göre, katılım bankalarının sektördeki payı 31/10/2019 itibarıyla toplanan fonda 8,1 ve kullandırılan fonda 5,2 olarak gerçekleşmiştir (TKBB, 2019). 
konuda oldukça az sayıda çalışma bulunmaktadır. Bu çalışmalarda da çoğunlukla, bireylerin İslami finans okuryazarlık seviyesi ve buna etki eden faktörler incelenerek analizler tamamlamaktadır. Bu araştırmada ise bir adım daha ileri gidilerek İslami finans okuryazarlık düzeyinin finansal okuryazarlık ile ilişkisi incelenmiş, ayrıca bu düzeyin İslami finans özelinde finansal davranışlara olan etkileri analiz edilmiştir. Böylelikle, bu araştırmanın yeni gelişmekte olan İslami finans okuryazarlığı alanına özgün bir katkı sağlayarak ve bu konuda öncü olması hedeflenmektedir.

\section{Literatür}

\subsection{Finansal Okuryazarlık}

Finansal sistemin gelişip yaygınlaşarak bireylerin hayatlarında önemli bir yer edinmeye başlamasıyla birlikte finansal okuryazarlık konusu da önem kazanmıştır. Bu konuyla ilgili uluslararası literatürde, bireylerin finansal okuryazarlık düzeyinin ölçülmesinden (Volpe, Chen, v.d., 1996; Beal ve Delpachitra, 2003; Mandell, 2008) finansal okuryazarlığın cinsiyete göre farklılaşmasına (Chen ve Volpe, 2002; Lusardi ve Mitchell, 2008) ve yaş gruplarına göre karşılaştırmasına (Bowen, 2002), finansal okuryazarlık düzeyinin finansal davranışlara olan etkisinden (Lusardi ve Mitchell, 2007; Servon ve Kaestner, 2008) bireylere finans eğitimi verilmesinin önemine (Bernheim ve Garrett, 2003; Fox, Bartholomae, v.d., 2005) kadar çeşitli araştırmalar bulunmaktadır.

2008 Küresel Finans Krizinin ardından ise hem ülkeler hem de uluslararası kuruluşlar nezdinde finansal okuryazarlık konusu daha da dikkat çekmiştir. Birçok kuruluş bu konuyla alakalı çalışmalar yapmış ve finansal eğitimler hazırlayarak bireylerin finansal okuryazarlık düzeyini artırmayı amaçlamıştır. Öte yandan, akademik araştırmalar da artarak ve derinleşerek devam etmiştir (van Rooij, Lusardi, v.d., 2011; Rasoaisi ve Kalebe, 2015; Lusardi ve Mitchell, 2015; Finke, Howe, v.d., 2016; Brent ve Ward, 2018; Bianchi, 2018).

Finansal okuryazarlık Türkiye' de de birçok çalışmaya konu olmuştur. Bu çalışmaların büyük bir kısmı üniversite öğrencilerine uygulanan anket doğrultusunda finansal okuryazarlık düzeyinin ölçülmesini ve buna etki eden faktörlerin incelenmesini içermektedir. Bunun dışında, banka müşterileri (Baysa ve Karaca, 2016), akademik ve idari personeller (Gutnu ve Cihangir, 2015; Öztürk ve Demir, 2015), kamu çalışanları (Şahin ve Barış, 2017) gibi farklı gruplarla da finansal okuryazarlık araştırmaları yapılmıştır. Hâlâ güncelliğini korumakta olan bu konunun daha detaylı ve derinlemesine çalışlarak bireylerin iktisadi davranışlarına, finansal sisteme ve 
makroekonomik değişkenelere etkisinin araştırıması önem taşımaktadır.

Finansal okuryazarlık konusunu öğrencilere uygulanan anket verileri üzerinden inceleyen Alkaya ve Yağlı (2015) Nevşehir Hacı Bektaş Veli Üniversitesinde, Coşkun (2016) Celal Bayar Üniversitesinde, ve Çam ve Barut (2015) Gümüşhane Üniversitesinde yaptığı araştırmalarda finansal okuryazarlık düzeyinin düşük olduğunu söylemiştir. Öte yandan, Kılıç, Ata, v.d. (2015) Gaziantep Üniversitesindeki ve Şamiloğlu, Kahraman, v.d. (2016) Erciyes Üniversitesindeki araştırmalarında erkek öğrencilerin finansal okuryazarlık düzeyinin daha yüksek olduğunu tespit etmiştir. Kılıç, Ata, v.d. (2015) ayrıca kredi kartı ve internet bankacılığı kullanımının öğrencilerin finansal okuryazarlığını olumlu etkilediğini; Şamiloğlu, Kahraman, v.d. (2016) ise öğrenim görülen fakülte ve ailenin eğitim durumunun etkili olduğunu göstermiştir. Kocabıyık ve Teker (2018) de Süleyman Demirel Üniversitesindeki araştırmasında cinsiyet ile fakültenin finansal okuryazarlık düzeyini anlamlı olarak etkilediğini belirlemiştir. Osmaniye Korkut Ata Üniversitesinde anket çalışması yapan Ergün, Şahin, v.d. (2014), cinsiyet ve hanehalkı gelirinin finansal okuryazarlığa etki ettiğini; fakat genel not ortalaması ile ailenin eğitim seviyesinin anlamlı bir etkisi olmadığını göstermiştir.

\section{2. İslami Finans Okuryazarlığı}

Son yıllarda finans sektöründe yaşanan gelişmelere paralel olarak, İslami finans sektörü de gelişerek genel finans sistemi içerisinde kendisine yer açmıştır. Bu noktada, bireylerin İslami finans okuryazarlık düzeyinin belirlenmesi ve bunun İslami finans sisteminin yaygınlaşmasına olan etkisinin anlaşılması önem kazanmıştır. Buna rağmen, bu konuda yapılmış olan çalışmalar oldukça sınırlı sayıdadır.

Abdullah ve Chong (2014) literatür taraması şeklinde yaptıkları araştırmalarında, finansal okuryazarlık kavramının tanımlanması, finansal okuryazarlık seviyesinin ölçülmesi ve analiz edilmesi amacıyla yapılmış pek çok çalışma olmasına rağmen, İslami finans okuryazarlığı konusunda çok az sayıda çalışma bulunduğunu göstermiştir. Hidajat ve Hamdani (2017) İslami finansın hızla geliştiği günümüzde İslami finans okuryazarlık düzeyini ölçmek için bir endeks bulunmadığını belirterek, bunun İslami finansın gelişmesine etkileri açısından önemli olduğunu söylemiştir.

İslami finans okuryazarlığı kavramının henüz tam olarak net bir tanımının olmadığını söyleyen Antara, Musa, v.d. (2016), bireylerin İslami finans okuryazarlığını tespit etmek için temel İslami finans ilkeleri ile murabaha, müşareke, mudaraba gibi İslami finans yöntemleri hakkında sorular yönelterek bu konudaki bilgi seviyelerini ölçmeyi 
amaçlamışlardır. İslami finans okuryazarlığını, finansal bilgi, finansal tutum ve finansal davranışın İslami usullere göre şekillendirilmesi olarak tanımlayan Rahim, Rashid, v.d. (2016), bu doğrultuda anket soruları hazırlayarak Malezya Utara Üniversitesinin öğrencilerine uygulamıştır. Böylece öğrencilerin İslami finans okuryazarlığını ve bunu etkileyebilecek dindarlık, çaresizlik ve mali tatmin gibi faktörleri araştırmıştır. Abdullah, Wahab, v.d. (2017) da Maleyza'da üniversite öğrencilerine yaptıkları anket ile onların İslami finans okuryazarlık seviyesini ölçerek bu seviyeyi belirleyici cinsiyet, eğitim, kişisel finans yönetimine ve İslami finans ürünlerine karşı tutum gibi etkenleri incelemiştir. Diğer taraftan, Rammal ve Zurbruegg (2016) ise Avustralya'daki müslümanların İslami bankacılık ürünleri farkındalık seviyesini analiz etmiştir.

Türkiye' de İslami finans okuryazarlığı henüz daha yeni yeni tanınma aşamasındadır. Er, Mutlu, v.d. (2015) Karadeniz Teknik Üniversitesinde İktisadi ve İdari Bilimler ile İlahiyat fakültelerinin öğrencilerine anket uygulaması yaparak, İslami finans okuryazarlık düzeylerini karşılaştırmalı analiz etmiştir. İslami finans okuryazarlık düzeyinin genelde düşük olduğunu, bununla birlikte İlahiyat öğrencilerinin diğerlerine kıyasla daha yüksek düzeye sahip olduğunu belirlemiştir. Öğrencinin cinsiyeti, İslam ekonomisi alanında ders alması ve katılım bankası kullanmış olmasının da İslami finans okuryazarlık düzeyini etkilediğini tespit etmiş̧ir.

Er ve Mutlu (2017) bireylerin İslami finans okuryazarlık seviyesini ölçebilecek bir anket geliştirmeyi ve İslami finans okuryazarlık endeksi oluşturmayı amaçlamıştır. Bu doğrultuda, OECD finansal okuryazarlık endeksine dayanarak dört farklı endeks üretmiştir. Bunlar İslami finans bilgi endeksi, İslami finans tutum endeksi, İslami finans davranış endeksi ve üçünden türetilmiş i̇slami finans okuryazarlık endeksidir.

Bekereci, Ayrıçay, v.d. (2017) araştırmalarında Rahim, Rashid, v.d. (2016) tarafından geliştirilen ölçeği Kahramanmaraş Sütçü İmam Üniversitesi öğrencilerine uygulayarak İslami finansal okuryazarlık düzeyini ve buna etki edebilecek psikolojik faktörleri analiz etmişlerdir. Bu düzeyin inanç düzlemi ve finansal uygulama düzleminde farklılaştığını tespit etmiş; ve üniversitelerde ilahiyat bilgisi olanların finans bilgisi eksikliğinin, finans bilgisi olanların da ilahiyat bilgisi eksikliğinin giderilmesiyle öğrencilerin İslami finansal okuryazarlık düzeyinin artırabileceğini söylemişlerdir.

Çömlekçi (2017) ise Antara, Musa, v.d. (2016)'nın araştırmasındaki soruları kullanarak katılım bankası müşterilerinin İslami finans bilgileri ve okuryazarlık düzeylerini incelemiştir. Bu düzeylerin banka müşterileri arasında genel olarak düşük olduğu; bununla beraber cinsiyet, yaş, eğitim, meslek ve gelire göre anlamlı farklıık gösterdiği sonucuna ulaşmıştır. 
Durmuş ve Yardımcıoğlu (2018) Sakarya Üniversitesi Illahiyat fakültesi öğrencilerinin İslami finans okuryazarlık seviyesini analiz etmiştir. Öğrencilerin temel ekonomi ve finans bilgisinin orta seviyede olduğunu; fakat İslami finansın temel ilkeleri, katılım bankacılığı ve İslami finans ürünleri hakkındaki bilgi seviyelerinin bir hayli düşük olduğunu tespit etmiştir. İslami finans okuryazarlık seviyesinin bu alanda eğitim, seminer ve konferanslar düzenlenerek arttırılabileceğini belirtmiştir.

\section{Araştırma}

\subsection{Araştırmanın Amacı}

Bu araştırma, İslami finans sisteminin her geçen gün biraz daha geliştiği ve yaygınlaştığı günümüz Türkiye'sinde, üniversite öğrencilerinin İslami finans konusundaki farkındalığını ve okuryazarlığını detaylı bir şekilde analiz etmeyi amaçlamaktadır. Araştırma kapsamında özel hazırlanmış sorular ile öğrencilerin İslami finans okuryazarlık seviyesi ölçülmüş ve İslami finans okuryazarlığına etki eden faktörler incelenmiştir. Bunun yanı sıra, öğrencilerin finansal okuryazarlık seviyesine bakılarak, İslami finans okuryazarlığı ile ilişkisi araştırımıştır.

Araştırmada İslami finans okuryazarlığının, öğrencilerin İslami finans sistemi ve katılım bankacılığı hakkındaki düşüncelerine ve finansal tercihlerine olan etkisi de analiz edilmiştir. Böylece, bu araştırma Türkiye'deki katılım bankacılığı kullanımı vasıtasıyla İslami finansın yayılmasında ve faizsiz finans sektörünün büyümesinde İslami finans okuryazarlığının rolünü incelemeyi amaçlamıştır.

\subsection{Veri Toplama Aracı}

Bu araştırma için anket çalışması yapılmıştır. İstanbul Sabahattin Zaim Üniversitesi'nde uygulanmak üzere üniversite öğrencilerine yönelik hazırlanan bu anket, toplamda 4 bölüm ve 33 sorudan oluşmaktadır. Anketin ilk bölümünde, öğrencilere demografik bilgilerinin yanı sıra parayla ve bankayla olan ilişkileri sorulmuştur. İkinci bölüm, finansal okuryazarlık düzeyini ölçmeyi amaçlayarak, OECD INFE (Finansal Eğitime Yönelik Uluslararası İşbirliği) tarafından geliştirilen ve birçok ülkede farklı yaş gruplarından insanlara uygulanan dokuz tane soruyu içermektedir (OECD/INFE, 2011). Bunlar Türkçe'ye çevrilerek öğrencilere yöneltilmiştir.

Anketin son iki bölümündeki sorular, öğrencilerin İslami finans farkındalığını, İslami finans ve katılım bankacılığı alanındaki bilgisini, katılım bankası kullanımını ve günümüzde kullanılan İslami finans yöntemleri hakkındaki düşüncesini araştırmayı amaçlamıştır. Üçüncü bölümde İslami finans okuryazarlık düzeyini ölçmek üzere 
hazırlanan altı tane soru bulunurken; dördüncü bölümde ise İslami finans sistemi özelinde öğrencilerin finansal davranışları ile ilgili sorular sorulmuştur. ${ }^{4}$

\subsection{Araştırmanın Örneklemi}

Bu araştırma için hazırlanan anket soruları İstanbul Sabahattin Zaim Üniversitesi' nin lisans öğrencilerine yöneltilmiş ve 376 öğrenciden veri toplanmıştır. Bunlardan 13 tanesi İslami finans okuryazarlığı ve İslami finansal sisteme katılım ile ilgili soruları, yani anketin üçüncü ve dördüncü bölümlerini, tamamen boş bıraktığı için çıkartılarak araştırma 363 öğrenci üzerinden gerçekleştirilmiştir. ${ }^{5}$ Anketler, yüz yüze görüşme tekniği kullanılarak grup olarak öğrencilere sınıf ortamında uygulanmıştır. Tablo 1, öğrencilerin demografik bilgilerine ait özet istatistikleri göstermektedir.

Tablo 1. Demografik Bilgiler

\begin{tabular}{|c|c|c|c|c|c|c|c|}
\hline & & $\mathrm{N}$ & $\%$ & & & $\mathrm{~N}$ & $\%$ \\
\hline \multirow[b]{2}{*}{ Cinsiyet } & Bay & 160 & 44,1 & \multirow[b]{2}{*}{ Fakülte } & IYBF & 158 & 43,8 \\
\hline & Bayan & 203 & 55,9 & & $\begin{array}{l}\text { Diğer } \\
\text { Fakülteler }\end{array}$ & 203 & 56,2 \\
\hline \multirow{5}{*}{ Yaş } & $18-19$ & 84 & 23,3 & \multirow{5}{*}{$\begin{array}{l}\text { Okuduğu } \\
\text { Sınıf }\end{array}$} & 1. $\sin$ if & 200 & 55,6 \\
\hline & $20-21$ & 182 & 50,6 & & 2. sinif & 105 & 29,1 \\
\hline & $22-23$ & 71 & 19,7 & & 3. $\sin i f$ & 32 & 8,9 \\
\hline & $24-25$ & 10 & 2,8 & & 4. $\sin i f$ & 21 & 5,8 \\
\hline & 26 ve üstü & 13 & 3,6 & & 4. sınıf üstü & 2 & 0,6 \\
\hline \multirow{4}{*}{$\begin{array}{l}\text { Baba } \\
\text { Eğitimi }\end{array}$} & $\begin{array}{l}\text { Okuryazar } \\
\text { değil }\end{array}$ & 1 & 0,3 & \multirow{4}{*}{$\begin{array}{l}\text { Anne } \\
\text { Eğitimi }\end{array}$} & $\begin{array}{l}\text { Okuryazar } \\
\text { değil }\end{array}$ & 14 & 3,9 \\
\hline & Illköğretim & 113 & 31,4 & & İlköğretim & 190 & 52,6 \\
\hline & Lise & 134 & 37,2 & & Lise & 123 & 34,1 \\
\hline & $\begin{array}{l}\text { Üniversite } \\
\text { ve üstü }\end{array}$ & 112 & 31,1 & & $\begin{array}{l}\text { Üniversite } \\
\text { ve üstü }\end{array}$ & 34 & 9,4 \\
\hline
\end{tabular}

Not: N=363. Örneklemdeki öğrencilerin yaş aralığı 18-49 arasında değişmektedir. Tablodaki "Diğer Fakülteler", üniversitedeki İşletme ve Yönetim Bilimleri Fakültesi (IYBF) haricindeki altı fakültenin (Eğitim; Mühendislik ve Doğa Bilimleri; Insan ve Toplum Bilimleri; İslami ilimler; Hukuk; ve Sağlık Bilimleri) öğrencilerini içermektedir.

Farklı fakülte ve bölümlerden öğrencilere ulaşabilmek amacıyla anketlerin yarısı bütün lisans öğrencilerinin aldığı Ortak Seçmeli Dersler esnasında yapılmıştır. Kalanı ise Işletme ve Yönetim Bilimleri Fakültesi (IYBF) bölümlerinde okuyan öğrencilere

4 İslami finans okuryazarlık düzeyini ölçmeyi amaçlayan sorular, İslam ekonomisi ve i̇slami finans alanlarında çalışmalar yapan akademisyenlerle istişare edilerek yazar tarafından hazırlanmıştır.

5 Anketler, öğrencilere 2017 yılının Nisan ve Mayıs aylarında yapılmıştır. İstanbul S. Zaim Üniversitesi'nin 2017 yılında 5156 lisans öğrencisi bulunmaktadır (ISZU, 2017). Evren büyüklüğünün 5000 olduğu durumda heterojen örneklem ve \%5 hata payı öngörülerek seçilen örnek büyüklüğü 357 olarak belirlenmiştir (Yazıııoğlu ve Erdoğan, 2004: 50). Araştırmadaki örneklem 363 öğrenci ile yeterli boyuttadır. 
kendi alan derslerinde dağıtılmıştır. ${ }^{6}$ Böylelikle, ekonomi veya finans eğitimi almanın finansal okuryazarlık ve İslami finans okuryazarlığı üzerindeki etkisinin karşılaştırmalı olarak analiz edilmesi amaçlanmıştır. Örneklemin \%44'ünü iYBF öğrencileri oluştururken, kalan kısmında üniversitenin diğer altı fakültesinin on yedi farklı bölümünden öğrenci bulunmaktadır. ${ }^{7}$

Üniversitenin genelinde olduğu gibi, örneklemde de erkek öğrenci oranı (\%44) kızlardan düşüktür. Fakat bu durum fakülte bazında farklılaşmaktadır: iYBF öğrencilerinin \%61'i, diğer fakültelerin ise sadece \%31'i erkektir. Örneklemdeki öğrencilerin yaşları, bekleneceği gibi, çoğunlukla 18 ile 23 arasında değişmektedir; bununla birlikte az sayıda da olsa 30'lu ve 40'lı yaşlarda öğrenciler bulunmaktadır. Örneklem, yarısı 1. sınıf olmak üzere, 4+'ya kadar bütün sınıflardan öğrenci içermektedir. Farklı eğitim seviyesindeki ailelerden gelen bu öğrencilerin \%33'ünün anne veya babası üniversite mezunu olduğu belirlenmiştir.

\subsection{Veri Analiz Yöntemi}

Anket çalışmasının sonucunda elde edilen veriler, IBM SPSS Statistics V25 kullanılarak analiz edilmiştir. Araştırmada, finansal okuryazarlık ve İslami finans okuryazarlık düzeyleri tanımlayıcı istatistiklerden ve hipotez testinden yararlanılarak incelenmiştir. Bu düzeylere etki eden faktörler analiz edilirken çoklu doğrusal regresyon yönteminden faydalanılmıştır. Bunun yanı sıra, İslami finans okuryazarlığının öğrencilerin katılım bankaları hakkındaki düşüncesine ve İslami finans sistemine katılımına olan etkisi araştırıırken ikili lojistik regresyon analizi yapılmıştır.

\section{Bulgular}

Bu bölümde, öncelikle üniversite öğrencilerinin ekonomik hayatla ve finansal sistemle ilişkileri incelenmiştir. Daha sonra öğrencilerin finansal okuryazarlık seviyesi ölçülerek bunu belirleyen etkenlere bakılmıştır. Son olarak da İslami finans okuryazarlığı konusuna geçilerek öğrencilerin İslami finans okuryazarlık düzeyi belirlenmiş; bu düzeye etki eden demografik ve ekonomik faktörler araştırılarak finansal okuryazarlıkla ilişkisi incelenmiş; ayrıca bu düzeyin öğrencilerin finansal tercihlerine olan etkisi analiz edilmiştir.

6 iYBF'de İşletme, ìktisat, Uluslararası Ticaret ve Finans, ve İslam Ekonomisi ve Finans bölümleri bulunmaktadır.

7 Örneklemde, IYYBF haricinde, Mühendislik ve Doğa Bilimleri Fakültesi'nin Bilgisayar Mühendisliği, Endüstri Mühendisliği, Gıda Mühendisliği, ve Mimarlık; Hukuk Fakültesi; İnsan ve Toplum Bilimleri Fakültesi'nin Siyaset Bilimi ve Uluslararası İlişkiler, Psikoloji, Sosyoloji, ve Tarih; Sağlık Bilimleri Fakültesi'nin Sosyal Hizmet, Sağlık Yönetimi, Beslenme ve Diyetetik, ve Hemşirelik; İslami Ilimler Fakültesi; ve Eğitim Fakültesi'nin Rehberlik ve Psikolojik Danışmanlık, İngilizce Öğretmenliği, ve Türkçe Öğretmenliği öğrencileri bulunmaktadır. 
Tablo 2. Ekonomik/Finansal Hayatla İlişkiler

\begin{tabular}{|c|c|c|c|c|c|c|c|}
\hline & & $N$ & $\%$ & & & $\mathrm{~N}$ & $\%$ \\
\hline \multirow{3}{*}{$\begin{array}{l}\text { Çalışma } \\
\text { Durumu }\end{array}$} & $\begin{array}{l}\text { Hiçbir işte } \\
\text { çalışmadım }\end{array}$ & 158 & 43,5 & \multirow{4}{*}{$\begin{array}{l}\text { Para } \\
\text { Birikimi }\end{array}$} & Biriktirmem & 40 & 11,1 \\
\hline & Çalışıyorum & 62 & 17,1 & & $\begin{array}{l}\text { Satın almak } \\
\text { istediğim bir şey } \\
\text { olursa biriktiririm }\end{array}$ & 98 & 27,2 \\
\hline & $\begin{array}{l}\text { Daha önce } \\
\text { çalışmıştım }\end{array}$ & 143 & 39,4 & & $\begin{array}{l}\text { Ara sıra } \\
\text { biriktiririm }\end{array}$ & 143 & 39,7 \\
\hline \multirow{3}{*}{$\begin{array}{l}\text { Banka } \\
\text { Hesabı } \\
\text { Bulunması }\end{array}$} & Evet & 286 & 78,8 & & $\begin{array}{l}\text { Düzenli olarak } \\
\text { biriktiririm }\end{array}$ & 79 & 21,9 \\
\hline & Hayır & 76 & 20,9 & \multirow{2}{*}{$\begin{array}{l}\text { Para K. } \\
\text { Merak }\end{array}$} & Evet & 280 & 77,6 \\
\hline & Bilmiyorum & 1 & 0,3 & & Hayır & 81 & 22,4 \\
\hline \multirow{3}{*}{$\begin{array}{l}\text { İnternet } \\
\text { Bankacılığı } \\
\text { Kullanması }\end{array}$} & Evet & 212 & 58,4 & \multirow{5}{*}{$\begin{array}{l}\text { Para } \\
\text { K. Bilgi } \\
\text { Edinilen } \\
\text { Kaynak }\end{array}$} & Aile & 135 & 37,4 \\
\hline & Hayır & 150 & 41,3 & & Arkadaş & 52 & 14,4 \\
\hline & Bilmiyorum & 1 & 0,3 & & İnternet & 159 & 44,0 \\
\hline \multirow{2}{*}{$\begin{array}{l}\text { Kredi Kartı } \\
\text { Kullanması }\end{array}$} & Evet & 165 & 45,5 & & Kitap & 18 & 5,0 \\
\hline & Hayır & 198 & 54,5 & & Diğer & 37 & 10,2 \\
\hline
\end{tabular}

Not: N=363. Tabloda çalışma durumu; banka hesabı, internet bankacılı̆̆ı ve kredi kartı kullanımı; para biriktirme düzeni; yatırım, tasarruf ve bankacılık gibi parayla ilgili konulara olan merakı; ve para konularını merak edenlerin hangi kaynaklardan bilgi edindiğine dair öğrenci sayıları ve yüzdeleri gösterilmiştir.

Araştırmada öğrencilerin iktisadi ve finansal hayatla ilişkilerini anlamak amacıyla onlara çalışma durumları, birikim düzenleri, parayla alakalı konulara olan merakları, ve banka hesabı, internet bankacılığı ve kredi kartı kullanımları sorulmuştur. Bu sorulara ait istatistikler Tablo 2'de verilmektedir. Çoğunluğu henüz 20'li yaşlarının başında olan ve lisans eğitimine devam eden bu öğrencilerin \%39'u daha önce bir işte çalıştığını, \%17'si şu anda çalışıyor olduğunu, kalanı ise hiçbir işte çalışmadığını belirtmiştir. Bu da öğrencilerin yarıdan fazlasının, kısa süreli dahi olsa, çalışma hayatı içerisinde bulunduğunu göstermektedir. Diğer taraftan, öğrencilerin \%22'si düzenli olarak para biriktiğini söylerken \%40'ı ara sıra ve \%27'si de satın almak istediği bir şey olursa biriktirdiğini belirtmiştir. Hiç biriktirmediğini söyleyen \%11'dir. Üniversitede öğrencilerin değişen burs oranlarında öğrenim gördükleri göz önüne alınırsa, örneklemde farklı sosyo-ekonomik koşullardan kişilerin olduğu ve bunun onların birikim yapmasını etkilediği düşünülebilir. Buna rağmen, öğrencilerin büyük kısmının para biriktirme bilinçlerinin ve alışkanlıklarının olduğu görülmektedir.

Araştırmada öğrencilerin \%78'i yatırım, tasarruf, bankacılık gibi parayla ilgili konuları merak ederek çeşitli kaynaklardan araştırdıklarını söylemiştir. Bekleneceği 
gibi, bu oran IYBF öğrencilerinde (\%85) diğerlerinden (\%72) daha yüksektir. Örneklemde hukuktan psikolojiye, mühendislikten hemşireliğe ve öğretmenliklere kadar pek çok farklı alandan öğrencinin olduğu düşünülecek olursa, bu oran yüksek olarak değerlendirilebilir. Para konularını merak edenlerin bilgi edinebilmek için çoğunlukla interneti tercih ettiği (\%44) veya ailesiyle konuştuğu (\%37) görülmektedir. Arkadaş (14\%) ve kitap (5\%) gibi alternatifler ise pek tercih edilmemektedir. Bunun yanı sıra, araştırmaya katılan öğrencilerin \%85'inin banka hesabı, internet bankacılığı veya kredi kartı kullanımı ile bankacıı sistemine dahil oldukları anlaşılmaktadır. Öğrencilerin \%79'u banka hesabının bulunduğunu, \%58'i internet bankacılığı hizmetlerinden yararlandığını ve \%45'i de kredi kartı kullanıyor olduğunu belirtmiş̧tir.

\subsection{Finansal Okuryazarlık Analizi}

\subsubsection{Finansal Okuryazarlık Düzeyinin Belirlenmesi}

Bu araştırmada üniversite öğrencilerinin finansal okuryazarlık seviyesi, OECD/ INFE'nin geliştirdiği dokuz soru kullanılarak ölçülmüştür. Bunlar, enflasyon bilgisi, basit ve bileşik faiz hesaplaması, risk çeşitlendirmesi gibi temel finans bilgilerini içermektedir. Bu sorulara doğru ve yanlış cevap veren öğrenci yüzdeleri Tablo 3'te gösterilmiştir.

Tablo 3. Finansal Okuryazarlık Soruları

\begin{tabular}{|c|l|c|c|c|}
\hline & & Doğru Cevap & Yanlış Cevap & Bilmiyorum / Cevap Yok \\
\hline 1 & Basit Bölme Işlemi & 98,6 & 1,1 & 0,3 \\
\hline 2 & Paranın Zaman Değeri & 51,2 & 24,2 & 24,6 \\
\hline 3 & Faiz Ödemesi & 90,1 & 2,7 & 7,2 \\
\hline 4 & Basit Faiz Hesaplama & 70,5 & 9,4 & 20,1 \\
\hline 5 & Bileşik Faiz Hesaplama & 36,9 & 48,0 & 15,3 \\
\hline 6 & Risk-Getiri Ilişkisi & 73,0 & 15,2 & 11,8 \\
\hline 7 & Enflasyon Farkındalığı & 59,5 & 23,7 & 37,8 \\
\hline 8 & Çeşitlendirme (Borsa) & 39,1 & 23,1 & 20,4 \\
\hline 9 & Çeşitlendirme (Tasarruf) & 65,8 & 13,8 & 16,8 \\
\hline
\end{tabular}

Not: N=363. Tabloda her bir soru için öğrencilerin cevap yüzdeleri verilmiştir. 
Finansal okuryazarlık seviyesini ölçmek için öğrencilere ilk olarak sorulan basit finansal bölme işlemini neredeyse tamamı doğru cevaplamıştır. Faiz ile ilgili sorulardan, borca yapılan faiz ödemesinin miktarını öğrencilerin \%90'ı bilirken, basit faiz hesabını \%71'i yapabilmiş ve bileşik faizi ise sadece \%37'si hesaplayabilmiştir. Bu oranlar, OECD/INFE'nin yetişkinlerin finansal okuryazarlığı üzerine yaptığı araştırmadaki Türkiye sonuçlarından çok daha yüksektir. İlk iki faiz sorusundaki öğrenci yüzdeleri, aynı zamanda OECD ülkeleri ortalamasının da biraz üzerinde bulunmaktadır (OECD/ INFE, 2016: 24). ${ }^{8}$

Araştırmadaki enflasyon ile ilgili sorular dikkat çekici sonuçlar vermiştir. Öğrencilerin sadece \%53'ü enflasyonun zaman içerisinde kişilerin satın alma gücünü azaltacağını bilirken, \%60' da yüksek enflasyonun yaşam maliyetini hızla arttırdığını söyleyebilmiştir. OECD/INFE 2016 Raporu, bu yüzde oranlarının hem Türkiye hem de OECD ortalamasından düşük olduğunu göstermektedir. Özellikle enflasyon farkındalığı sorusunda Türkiye ve OECD oranları \%80'in üzerindedir (OECD/INFE, 2016: 24). ${ }^{9}$ Türkiye uzun yıllar yüksek enflasyon yaşamış; fakat son on yılda enflasyon genellikle tek haneli düzeyde seyretmiştir. Üniversite öğrencilerinin yaşları itibarıyla yüksek enflasyon dönemini yaşamamış olmaları, enflasyon konusunda yeterli farkındalığa sahip olmamalarını açıklayabilir.

Risk ile getiri arasındaki ilişkiyle ilgili sorulan soruyu öğrencilerin \%73'ü doğru bilmiştir. Fakat risk ve çeşitlendirme ilişkisi sorulduğunda doğru cevap oranı düşmektedir. Öğrencilerin \%66'sı tasarrufları çeşitli yerlerde değerlendirmenin birikimi kaybetme intimalini azaltacağını bilirken, borsadaki yatırım riskine çeşitlendirme yapmanın etkisi sorulduğu zaman ise sadece \%39'u doğru cevap verebilmiştir. ${ }^{10}$ Bu sonuçlar öğrencilerin çoğunun çeşitlendirmeden ziyade borsa hakkında bilgi eksikliğinin bulunması şeklinde yorumlanabilir. Nitekim, borsadaki çeşitlendirmeye dair sorulmuş olan soruya verilen 'bilmiyorum' cevabının yüksek oranı (\%38) da bunu desteklemektedir. Öğrencilerin risk-getiri ve çeşitlendirme sorularındaki doğru cevap yüzdesi, OECD/INFE Raporunda açıklanan Türkiye yüzdelerinden de OECD ortalamasından da çok daha düşüktür (OECD/INFE, 2016: 24). ${ }^{11}$

8 OECD/INFE'nin 2016' da yayınladığı rapor, 30 ülkeyi kapsamakta olup yetişkinlerin (18-79 yaş arası) finansal okuryazarlık yetkinliklerini araştırmaktadır. Rapora göre, Türkiye'de yetişkinlerin \%84'ü faiz ödemesi, \%54'ü basit faiz hesaplaması ve \%32'si de bileşik faiz hesaplaması sorusunu doğru cevaplamıştır. OECD ortalamaları ise sırasıyla, $\% 89$, \%65 ve \%48'tir (OECD/INFE, 2016: 24).

9 OECD/INFE 2016 Raporuna göre, Türkiye'deki (OECD ortalamasında) yetişkinlerin \%55'i (\%66'sı) paranın zaman değeri, \%84'ü (\%81'i) de enflasyon farkındalığı sorusuna doğru cevap vermiştir (OECD/INFE, 2016: 24).

10 Araştırmadaki ülkelerin tamamına uygulanabilmesi amacıyla, OECD/INFE anketinde çeşitlendirme ile ilgili iki alternatif soru kullanmıştır. Bu araştırmada öğrencilere her iki de (hem borsa hem de tasarruf) sorulmuştur.

11 OECD/INFE'nin yayınladığı rapora göre, Türkiye'de risk-getiri ilişkisi sorusunu doğru cevaplama oranı \%90 ve çeşitlendirme sorusunu doğru cevaplama oranı \%83'tür. OECD ortalamasında ise bu oranlar $\% 83$ ve $\% 65^{\prime}$ tir. (OECD/INFE, 2016: 24). 
Öğrencilerin finansal okuryazarlık düzeyi, bu sorular temel alınarak, vermiş oldukları doğru cevap sayısıyla orantılı olarak artacak şekilde 0 ile 9 değerleri arasında tanımlanmıştır. Finansal okuryazarlık düzeyini belirlemek amacıyla kullanılan bu dokuz soru için iç tutarlılık güvenilirlik analizi yapılmış; güvenilirlik testi sonucunda Cronbach Alpha değeri 0,705 olarak bulunmuştur. Bu değerin 0,60'ın üzerinde olması, araştırmada finansal okuryazarlık düzeyini ölçmek için kullanılan soruların güvenilir olduğunu göstermektedir (Yazıcıoğlu ve Erdoğan, 2004: 64).

Şekil 1. Finansal Okuryazarlık Düzeyi

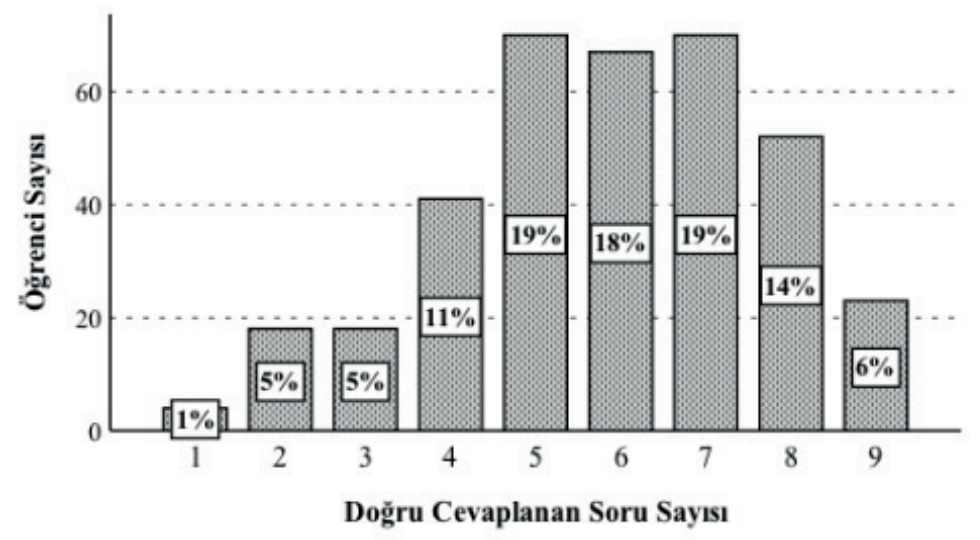

Öğrencilerin finansal okuryazarlık düzeyi dağılımı Şekil 1'de özetlenmiştir. Buna göre, araştırma kapsamında hiçbir soruyu doğru cevaplayamayan öğrenci olmadığı gibi, öğrencilerin yaklaşık \%90'ı en az dört soruya doğru cevap vermiştir. Araştırmadaki öğrencilerin finansal okuryazarlık ortalaması 5,85 (standart hatası 0,098 ) seviyesindedir.

Finansal okuryazarlık sorularına verilen doğru cevap oranları, tahmin edilebileceği üzere, iYBF'de diğer fakültelere göre daha yüksektir. IYBF'de finansal okuryazarlık düzeyi ortalama 6,39 iken diğer fakültelerde ise bu değer 5,42'dir. Hipotez testi (bağımsız örneklem t-testi) ile ortalamalar arasındaki fark analiz edildiğinde, dağılımda eşit varyans varsayımının saptanması ve bu doğrultudaki t-değerinin 5,010 olması ile aradaki farkın \%1 seviyesinde anlamlı olduğu belirlenmiştir.

\subsubsection{Finansal Okuryazarlık Düzeyine Etki Eden Faktörler}

Üniversite öğrencilerinin finansal okuryazarlık düzeyini etkileyen faktörleri incelemek amacıyla doğrusal regresyon analizi yapılmıştır. Burada bağımlı değişken, öğrencinin finansal okuryazarlık düzeyiyken; bağımsız değişkenler ise öğrencinin finansal okuryazarlık düzeyine etki edebileceği düşünülen ve literatürdeki analizlerde 
incelenen öğrencinin cinsiyeti, fakültesi, sınıfı ve ailesinin eğitim seviyesi gibi demografik bilgileri ile çalışma durumu, birikim düzeni, bankacılık sistemini kullanımı ve para konularına olan merakı gibi iktisadi ve finansal hayatla ilişkisine dair bilgilerini içermektedir (Bowen, 2002; Lusardi ve Mitchell, 2008; Ergün, Şahin, v.d., 2014; Kılıç, Ata, v.d., 2015; Şamiloğlu, Kahraman, v.d., 2016; Kocabıyık ve Teker, 2018).

Burada, finansal okuryazarlık düzeyi ve öğrencinin okuduğu sınıf haricindeki değişkenler 0/1 değeri alabilen kukla değişkenlerdir. Eğer öğrencinin cinsiyeti erkek; öğrenim gördüğü fakültesi IYBF; aile eğitim seviyesi anne veya babası üniversite mezunu; iş durumu çalışıyor veya daha önce çalışmış; para biriktirmesi düzenli; bankayla alakası banka hesabı olan, internet bankacılığı kullanan veya kredi kartı bulunan; ve para konularına merakı olduğunu söyleyen ise değişken 1 değerini alırken, diğer durumlarda 0 değerini almaktadır. Öte yandan, öğrencinin finansal okuryazarlık seviyesi 0 ile 9 aralığında, okuduğu sınıf ise 1 ile 5 aralığında değişen değerler alabilmektedir.

Regresyon analizinin sonuçları Tablo 4'te verilmiştir. Buna göre, öğrencinin cinsiyeti, öğrenim gördüğü fakültesi, para biriktirme düzeni ve para konusundaki merakı onun finansal okuryazarlığını \%5 anlamlıık seviyesinde etkilemektedir. Buna karşın, öğrencinin okuduğu sınıfın, ailesinin eğitim seviyesinin, iş durumunun ve bankayla alakasının finansal okuryazarlık düzeyi üzerine anlamlı bir etkisi bulunamamıştır.

Tablo 4. Finansal Okuryazarlık Analizi

\begin{tabular}{|c|c|c|c|c|}
\hline & \multicolumn{2}{|c|}{$\begin{array}{c}\text { Standartlaştırılmamış } \\
\text { Katsayılar }\end{array}$} & \multirow{2}{*}{$\begin{array}{l}\text { Standartlaştırılmış } \\
\text { Katsayılar Beta }\end{array}$} & \\
\hline & B & $\begin{array}{c}\text { Standart } \\
\text { Hata }\end{array}$ & & \\
\hline Cinsiyeti Erkek & 0,810 & 0,323 & 0,217 & $\star \star \star$ \\
\hline Fakültesi IYBF & 0,575 & 0,202 & 0,154 & 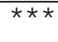 \\
\hline Okuduğu Sınıf & $-0,072$ & 0,194 & $-0,035$ & \\
\hline Aile Eğitimi Üniversite & $-0,005$ & 0,102 & $-0,001$ & \\
\hline İşte Çalışmış/Çalışıyor & 0,115 & 0,194 & 0,031 & \\
\hline Düzenli Para Birikimi & 0,512 & 0,196 & 0,114 & $\star \star \star$ \\
\hline Bankayla Alakalı & 0,344 & 0,220 & 0,067 & \\
\hline Para Konularına Meraklı & 0,928 & 0,257 & 0,208 & 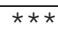 \\
\hline$R^{2}=0,211$ & \multicolumn{2}{|c|}{ Düzeltilmiş- $R^{2}=0,193$} & \multicolumn{2}{|c|}{$\mathrm{F}=11,395 * \star \star$} \\
\hline
\end{tabular}

Not: N=349. Regresyonda bağımlı değişken finansal okuryazarlık düzeyi; bağımsız değişkenler ise öğrencinin cinsiyeti, fakültesi, sınıfı, aile eğitim seviyesi, çalışma durumu, finansal birikim düzeni, bankayla alakası ve para konularına merakıdır. Tabloda ***, **, * sırasıyla \%1, \%5 ve \%10 anlamllık seviyelerini göstermektedir. 
Tablo 4'teki analiz sonuçları gösteriyor ki, diğer değişkenler sabit tutulduğunda, erkek öğrencilerin finansal okuryazarlık düzeyi kızlardan ortalama olarak 0,81 daha yüksektir. Bunun yanı sıra, eğitimleri işletme, iktisat veya finans üzerine olan IYBF öğrencileri, diğer fakültelerin öğrencilerinden ortalama 0,58 daha yüksek finansal okuryazarlığa sahiptir. Düzenli bir şekilde birikim yaptığını söyleyenlerin finansal okuryazarlık düzeyi, düzenli birikimi olmayanlara göre ortalama 0,51 daha fazladır. Ayrıca, yatırım, tasarruf ve bankacılık gibi parayla ilgili konulara meraklı olduğunu belirten öğrencilerin, bu konulara merakım yok diyenlerden ortalamada 0,93 daha yüksek finansal okuryazarlık düzeyine sahip olduğu görülmektedir.

\section{2. İslami Finans Okuryazarlığı Analizi}

\subsection{1. İslami Finans Okuryazarlık Düzeyinin Belirlenmesi}

İslami finansın son dönemde yakaladığı ivme ile daha da gelişip yaygınlaşmaya başladığı Türkiye' de, bu araştırma üniversite öğrencilerinin İslami finans okuryazarlığını incelemeyi amaçlamıştır. Bu doğrultuda, İslami finans okuryazarlık düzeyini ölçmek için İslami finansla ve katılım bankalarıyla alakalı giriş niteliğinde olan altı tane soru hazırlanmış ve öğrencilere yöneltilmiştir. Bu sorular ve sorulara verilen cevapların dağılımları Tablo 5'te sunulmuştur.

\section{Tablo 5. İslami Finans Okuryazarlığı Soruları}

\begin{tabular}{|c|c|c|c|c|}
\hline & & $\begin{array}{l}\text { Doğru } \\
\text { Cevap }\end{array}$ & $\begin{array}{l}\text { Yanlı̧ } \\
\text { Cevap }\end{array}$ & $\begin{array}{l}\text { Bilmiyorum } \\
\text { / Cevap Yok }\end{array}$ \\
\hline 1 & 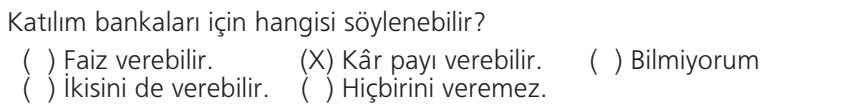 & 45,5 & 15,4 & 39,1 \\
\hline 2 & 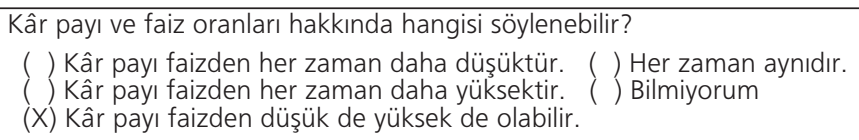 & 35,0 & 22,5 & 42,5 \\
\hline 3 & $\begin{array}{l}\text { "Katııım bankalarının faaliyet esası kâr ve zarar ortaklığına dayanır." } \\
\text { cümlesi... } \\
\begin{array}{lll}\text { (X) doğrudur. } & \text { ( ) yanlıştır. } & (\text { ) Bilmiyorum }\end{array}\end{array}$ & 48,5 & 8,8 & 42,7 \\
\hline 4 & $\begin{array}{l}\text { "İslami finans yöntemleri faizsizdir." cümlesi } \\
\begin{array}{lll}(\mathrm{X}) \text { doğrudur. } & (\text { ) yanlıştır. } & (\text { ) Bilmiyorum }\end{array}\end{array}$ & 62,8 & 14,9 & 22,3 \\
\hline 5 & $\begin{array}{l}\text { "Ev sahibi olmak isteyen birisi, katılım bankasından öncelikle parasını } \\
\text { alarak istediği yerden evi alabilir." cümlesi... } \\
\begin{array}{lll}(\text { ) doğrudur. } & (\mathrm{X}) \text { yanlıştır. } & (\text { ) Bilmiyorum }\end{array}\end{array}$ & 33,6 & 20,3 & 46,1 \\
\hline 6 & 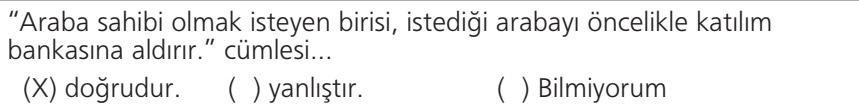 & 38,3 & 17,9 & 43,8 \\
\hline
\end{tabular}

Not: N=363. Tabloda öğrencilerin İslami finans okuryazarlık düzeyini ölçmek amacıyla hazırlanan anket soruları bulunmaktadır. Doğru cevaplar X ile işaretlenmiştir. Her soru için öğrencilerin cevap yüzdeleri verilmiştir. 
İslami finans okuryazarlık seviyesini ölçmek için hazırlanan bu sorulara geçilmeden önce, ankette öğrencilere klasik banka ile katılım bankası arasındaki farkı bilip bilmedikleri sorulmuştur. Öğrencilerin \%54'ü aradaki farkı bildiğini ve \%46'sı bilmediğini söylemiş̧tir. Bu oran her ne kadar yeni yeni yaygınlaşan İslami finans ve katııım bankacılı̆̆ı alanının bilinirliği için makul olarak değerlendirilebilecek bir büyüklükte olduğu düşünülse de bünyesinde İslam ekonomisi ve finans alanlarında lisans, yüksek lisans ve doktora programları bulunan, sertifika programları ve konferanslar düzenleyen İstanbul Sabahattin Zaim Üniversitesi'nde yapılmış olan bir anketin sonucunda ortaya çıkmış olması göz önünde bulundurulduğunda çok da yüksek olmadığı anlaşılacaktır. Tablo 5 gösteriyor ki, İslami finans okuryazarlık düzeyini ölçmek için sorulan sorulara verilen doğru cevap oranları aslında çok daha düşüktür.

İslam dininin ana hususlarından birisi olarak İslami finans yöntemlerinin de temelini oluşturan "faizsiz olmak" ilkesini öğrencilerin \%63'ü doğru bilmiştir. Bu soru, doğru cevap oranı en fazla olan sorudur; diğer sorularda bu oran yüzde ellinin altına inmektedir. Katııım bankasının kâr payı verebileceğini ama faiz veremeyeceğini öğrencilerin \%46'sı, kâr payının sabit bir değer olmadığını ve faiz oranından düşük de yüksek de olabileceğini ise \%35'i doğru cevaplamıştır. Bunun yanı sıra, katılım bankalarının faaliyet esasının kâr ve zarar ortaklığına dayandığını öğrencilerin \%49'u söyleyebilmiştir. Son iki soru, Türkiye' de katılım bankaları tarafından en çok uygulanan İslami finansman yöntemi (murabaha) hakkında biraz daha detay bilgi sormaktadır. ${ }^{12}$ Katılım bankası aracılığıyla ev veya araba almak isteyen kişinin izleyeceği yol ile ilgili sorulan sorulara öğrencilerden \%35 civarında doğru cevap gelmiştir.

Şekil 2. İslami Finans Okuryazarlık Düzeyi

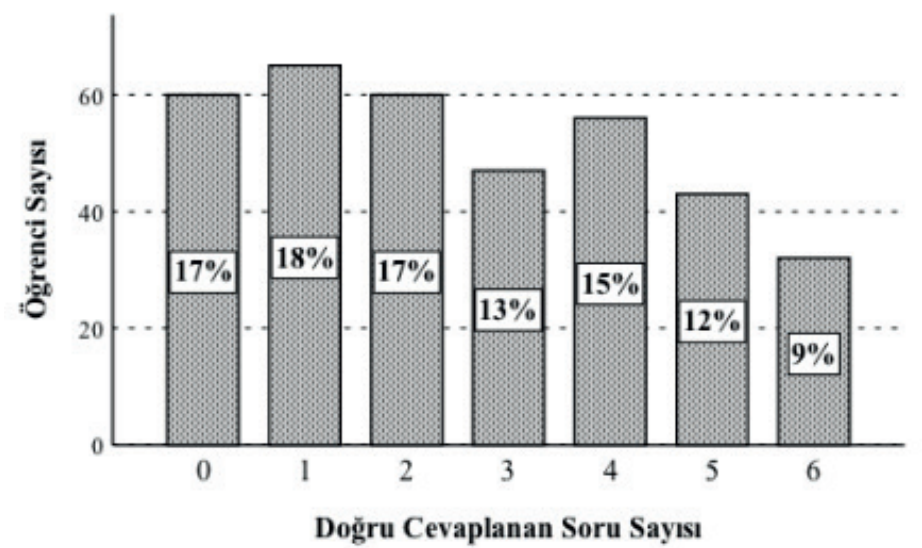

12 Türkiye'de, 2015 yılında, katılım bankaları tarafından en çok kullanılan İslami finansman yöntemi \%90 pay ile murabaha'dır. Onu icara'nın (\%5), istisna (\%2) ve selem (\%1) takip etmektedir (COMCEC, 2017: 110). 
Öğrencilerin İslami finans okuryazarlık düzeyi, finansal okuryazarlık analizinde olduğu gibi, sorulara verilen toplam doğru cevap sayısıyla ölçülerek 0 ile 6 arasında değer alabilecek şekilde tanımlanmışıı. İslami finans okuryazarlık düzeyini belirlemek amacıyla kullanılan bu altı soru için iç tutarlıık güvenilirlik testi yapıldığında Cronbach Alpha güvenilirlik katsayısı 0,822 olarak tespit edilmiştir. Bu değer İslami finans okuryazarlık düzeyini belirlemek için kullanılan anketin güvenilir olduğunu göstermektedir (Yazıcıoğlu ve Erdoğan, 2004: 64).

Öğrencilerin İslami finans okuryazarlık düzeyi dağılımı Şekil 2'de verilmiştir. Buradan, araştırmaya katılan öğrencilerin \%17'sinin İslami finans ve katılım bankalarıyla alakalalı hiçbir soruya doğru yanıt veremedikleri görülürken; yarıdan fazlasının ise en fazla iki soruyu doğru olarak bildiği anlaşımaktadır. Buna karşın, altı sorunun tamamını cevaplayabilen \%9 oranında öğrenci bulunmaktadır. Öğrencilerinin İslami finans okuryazarlığı ortalaması 2,64 (standart hatası 0,101) seviyesindedir.

Katılım bankası ve klasik banka arasındaki farkı bilip bilmemek konusunda öğrencilerin yaptıkları özbildirim ile onların İslami finans okuryazarlık düzeyi arasında tutarlı bir ilişki gözlenmiştir. Farkı bildiğini söyleyenlerin ortalama düzeyi 3,75 iken, bilmediğini söyleyenlerin ortalaması 1,32'dir. Aradaki farkı bilmediğini belirten öğrencilerin büyük bir kısmının İslami finans okuryazarlığı sorularının çoğunu "bilmiyorum" olarak cevapladığı görülmektedir.

İslami finans okuryazarlığı sorularını doğru yanıtlama yüzdesi, IYBF öğrencilerinde diğer fakültelerin öğrencilerine göre oldukça yüksektir. IYBF'de İslami finans okuryazarlı̆ı ortalama 3,54 düzeyindeyken, diğer fakültelerde ise ortalama 1,93'tür. Aradaki fark bağımsız örneklem t-testi yapılarak incelendiğinde, dağıımda varyans eşitliği varsayımının saptanması ve bu doğrultudaki t-değeri 8,718 ile ortalamalar arasında \%1 seviyesinde anlamlı bir fark olduğu tespit edilmiştir. IYBF bünyesinde İslam Ekonomisi ve Finans bölümünün bulunduğu, ayrıca fakültedeki diğer bölümlerin de seçmeli ders olarak bu alanlardan ders alma imkânlarının olduğu düşünülürse bu şaşırtıcı olmayan bir sonuçtur.

\subsection{2. İslami Finans Okuryazarlık Düzeyine Etki Eden Faktörler}

Öğrencinin İslami finans okuryazarlığını etkileyen faktörler, çok değişkenli doğrusal regresyon analizi yapılarak incelenmiştir. Bu regresyonun bağımlı değişkeni 0-6 arasında artan değerler alabilen İslami finans okuryazarlık düzeyidir. Bağımsız değişkenler ise bu düzeye etkisi olabileceği düşünülen öğrencinin finansal okuryazarlık düzeyinin yanı sıra, demografik özellikleri (cinsiyeti, fakültesi, sınıfı ve ailesinin eğitim 
seviyesi) ve finansal sistemle ilişkisini (çalışma durumu, para birikimi, bankacılık sistemiyle alakası ve para konularına olan merakı) kapsamaktadır. Bu demografik ve finansal hayatla ilişkili değişkenler, önceki bölümde finansal okuryazarlık analizinde de kullanılan değişkenlerdir. Böylece, her iki okuryazarlık düzeyine olan etkilerini karşılaştırma imkânı bulunmaktadır. Buna ilaveten, bu regresyon ile finansal okuryazarlığın İslami finans okuryazarlığına etkisi de incelenmektedir. Bu analizin sonuçları Tablo 6'da sunulmuştur.

Tablo 6'daki sonuçlar, İslami finans okuryazarlığı ile finansal okuryazarlık arasında \%1 anlamlılık seviyesinde pozitif bir ilişki bulunduğunu göstermektedir. Diğer değişkenler sabit tutulduğunda, öğrencinin finansal okuryazarlık düzeyindeki bir standart sapma $\left(\mathrm{SS}_{\mathrm{fo}}=0,098\right)$ artış ile birlikte İslami finans okuryazarlık düzeyinin 0,25 standart sapma $\left(\mathrm{SS}_{\text {ifo }}=0,101\right)$ arttığı görülmektedir.

Tablo 6. İslami Finans Okuryazarlığı Analizi

\begin{tabular}{|c|c|c|c|c|}
\hline & \multicolumn{2}{|c|}{$\begin{array}{c}\text { Standartlaştırılmamış } \\
\text { Katsayılar }\end{array}$} & \multirow{2}{*}{$\begin{array}{l}\text { Standartlaştırılmış } \\
\text { Katsayılar Beta }\end{array}$} & \\
\hline & B & $\begin{array}{c}\text { Standart } \\
\text { Hata }\end{array}$ & & \\
\hline Finansal Okuryazarlık & 0,255 & 0,374 & 0,246 & $\star \star \star$ \\
\hline Cinsiyeti Erkek & 0,329 & 0,051 & 0,085 & * \\
\hline Fakültesi IYBF & 1,182 & 0,196 & 0,305 & $\star \star \star$ \\
\hline Okuduğu Sınıf & 0,208 & 0,187 & 0,099 & $\star \star$ \\
\hline Aile Eğitimi Üniversite & 0,186 & 0,097 & 0,046 & \\
\hline İşte Çalışmış / Çalışıyor & 0,082 & 0,184 & 0,021 & \\
\hline Düzenli Para Birikimi & 0,120 & 0,187 & 0,026 & \\
\hline Bankayla Alakalı & 0,470 & 0,210 & 0,088 & $* *$ \\
\hline Para Konularına Meraklı & 0,780 & 0,244 & 0,168 & $\star \star \star$ \\
\hline$R^{2}=0,341$ & \multicolumn{2}{|c|}{ Düzeltilmiş- $R^{2}=0,323$} & \multicolumn{2}{|c|}{$\mathrm{F}=19,489 * * *$} \\
\hline
\end{tabular}

Not: N=349. Regresyonda bağımlı değişken İslami finans okuryazarlık düzeyi; bağımsız değişkenler öğrencinin finansal okuryazarlık düzeyi, cinsiyeti, fakültesi, sınıfı, aile eğitim seviyesi, çalışma durumu, finansal birikim düzeni, bankayla alakası ve para konularına merakıdır. Tabloda ***, **, * sırasıyla \%1, \%5 ve \%10 anlamlılık seviyelerini göstermektedir.

Bununla birlikte, öğrencinin cinsiyeti, fakültesi, sınıfı, bankacılık sistemiyle alakası ve parayla ilgili konulara merakı da İslami finans okuryazarlık üzerinde anlamlı etkiye sahiptir. Finansal okuryazarlıkta olduğu gibi, öğrencinin IYBF'de öğrenim görmesi ve para konularına meraklı olması İslami finans okuryazarlığını \%1 anlamlılık seviyesinde, pozitif ve oldukça büyük düzeylerde (sırasıyla 1,18 ve 0,78) etkilemektedir. Ayrıca, 
İslami finans okuryazarlık düzeyinin erkeklerde kız öğrencilerden 0,33 daha yüksek olduğu (\%10 anlamlılık seviyesinde) anlaşılmaktadır. Finansal okuryazarlıktan farkı olarak, öğrencinin okuduğu sınıfının her bir artışı 0,21; banka hesabı, internet bankacılığı veya kredi kartı kullanması da 0,47 düzeyinde İslami finans okuryazarlığını (\%5 anlamlılık seviyesinde) arttırmaktadır.

İslami finans okuryazarlık düzeyinin, finansal okuryazarlıkta da olduğu gibi, öğrencinin çalışma durumu ya da ailesinin eğitim seviyesiyle herhangi bir ilişkisi bulunamamıştır. Buna ilaveten, finansal okuryazarlığa pozitif etki eden öğrencinin düzenli şekilde para biriktirmesinin İslami finans okuryazarlık düzeyine bir etkisi olmadığı görülmektedir.

Üniversitenin İşletme ve Yönetim Bilimleri Fakültesi'nde (IYBF) İslam Ekonomisi ve Finans Bölümü bulunmaktadır. Bu bölümün öğrencilerinin İslami finans okuryazarlı̆ıının diğer öğrencilerden yüksek olması beklenir. Bu doğrultuda, regresyona öğrencinin fakültesi yerine, bölümü (eğer İslam Ekonomisi ve Finans ise 1, değilse 0 değeri alacak şekilde) kukla değişken olarak eklenerek analiz tekrar yapılmıştır. Tablo 7'de gösterilen sonuçlar bu beklentiyi doğrular niteliktedir. Buna göre, \%1 anlamlılık seviyesinde, İslam Ekonomisi ve Finans öğrencileri, üniversitenin diğer öğrencilerinden ortalama 1,84 daha yüksek İslami finans okuryazarlık düzeyine sahiptir.

Tablo 7. İslam Ekonomisi ve Finans Bölümü

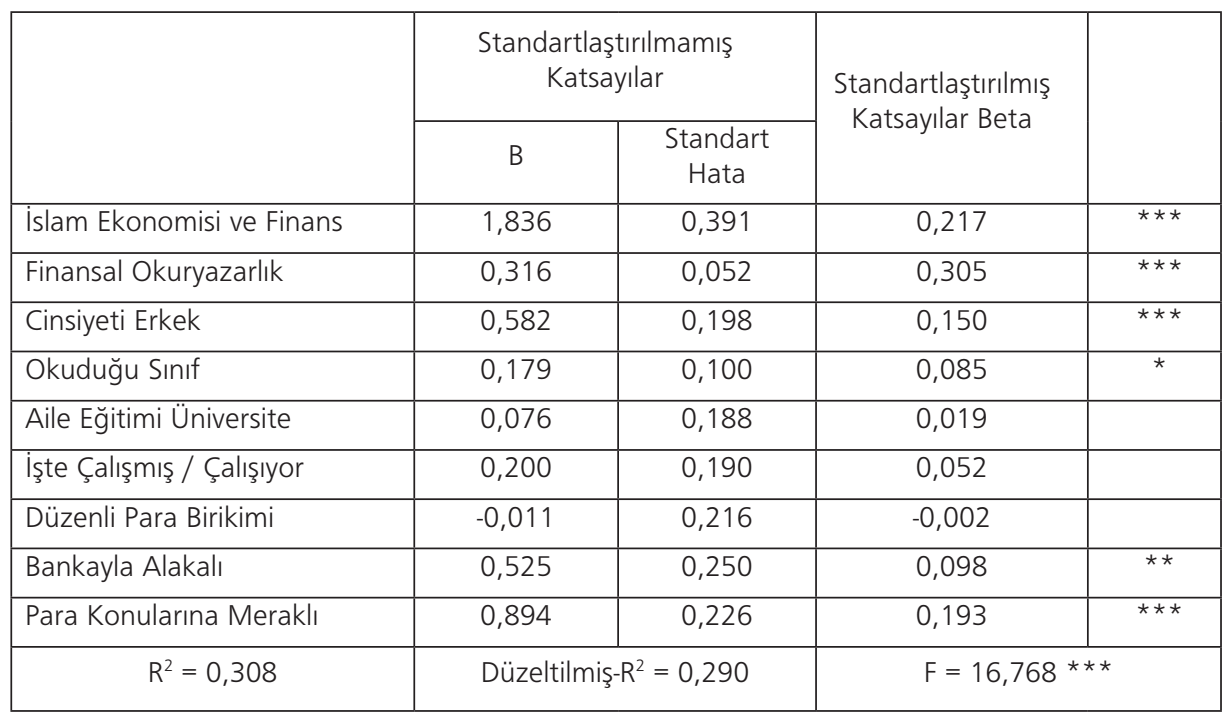

Not: N=349. Regresyonda bağımlı değişken İslami finans okuryazarlık düzeyi; bağımsız değişkenler öğrencinin bölümü, finansal okuryazarlık düzeyi, cinsiyeti, sınıfı, aile eğitim seviyesi, çalışma durumu, finansal birikim düzeni, bankayla alakası ve para konularına merakıdır. Tabloda ***, **, * sırasıyla \%1, \%5 ve \%10 anlamlılık seviyelerini göstermektedir. 


\begin{tabular}{|c|c|c|c|c|}
\hline & \multicolumn{2}{|c|}{$\begin{array}{c}\text { Standartlaştırılmamış } \\
\text { Katsayılar }\end{array}$} & \multirow{2}{*}{$\begin{array}{l}\text { Standartlaştırılmış } \\
\text { Katsayılar Beta }\end{array}$} & \\
\hline & B & $\begin{array}{c}\text { Standart } \\
\text { Hata }\end{array}$ & & \\
\hline İslami İlimler & $-0,747$ & 0,614 & $-0,058$ & \\
\hline Finansal Okuryazarlık & 0,310 & 0,054 & 0,299 & $* \star *$ \\
\hline Cinsiyeti Erkek & 0,553 & 0,203 & 0,143 & $* \star *$ \\
\hline Okuduğu Sınıf & 0,100 & 0,101 & 0,047 & \\
\hline Aile Eğitimi Üniversite & 0,095 & 0,194 & 0,023 & \\
\hline İşte Çalışmış / Çalışıyor & 0,185 & 0,196 & 0,048 & \\
\hline Düzenli Para Birikimi & 0,096 & 0,223 & 0,021 & \\
\hline Bankayla Alakalı & 0,502 & 0,258 & 0,094 & ** \\
\hline Para Konularına Meraklı & 0,811 & 0,236 & 0,175 & $* * *$ \\
\hline$R^{2}=0,266$ & \multicolumn{2}{|c|}{ Düzeltilmiş- $R^{2}=0,247$} & \multicolumn{2}{|c|}{$\mathrm{F}=13,672 * * *$} \\
\hline
\end{tabular}

Not: N=349. Regresyonda bağımlı değişken İslami finans okuryazarlık düzeyi; bağımsız değişkenler öğrencinin bölümü, finansal okuryazarlık düzeyi, cinsiyeti, sınıfı, aile eğitim seviyesi, çalışma durumu, finansal birikim düzeni, bankayla alakası ve para konularına merakıdır. Tabloda ***, **, * sırasıyla \%1, \%5 ve \%10 anlamlılık seviyelerini göstermektedir.

Üniversitenin bünyesinde İslami illimler Bölümü de bulunmaktadır. Bu bölümde okuyan öğrencilerin de İslami finans bilgilerinin iyi olacağı düşünülür. Nitekim, Er, Mutlu, v.d. (2015) Illahiyat öğrencilerinin daha yüksek düzeyde İslami finans okuryazarlığının olduğu sonucuna varmışlardır. Bu doğrultuda, regresyonda bölüm kukla değişkeni, İslami illimler okuyanların 1 ve diğerlerinin ise 0 değerini alacağı şekilde tanımlanarak analiz tekrar edilmiştir. Tablo 8'de verilen analiz sonuçlarına göre İslami illimler öğrencilerinin İslami finans okuryazarlığının diğer bölümlerin öğrencilerinden anlamlı bir farkı bulunamamıştır.

\subsection{3. İslami Finans Okuryazarlığının Finansal Tercihlere Etkisi}

Türkiye'de İslami finans henüz gelişme aşamasında olup cari finans sistemi içerisindeki payı oldukça küçüktür. Fakat son dönemde, kamu adına faaliyet gösteren katılım bankalarının açııması, bireysel emeklilik kapsamında faizsiz sistem alternatifinin sunulması, devletin altına dayalı kira sertifikası ihraç etmesi ve üniversitelerde İslami ekonomisi ve finans bölümlerinin açılması gibi gelişmelerle birlikte Türkiye'de İslami finans ilerleme kaydetmeye başlamıştır. Toplumdaki İslami finans farkındalığı ve okuryazarlığının bu gelişme ve ilerlemeye doğrudan veya dolaylı olarak bir katkısı olup olmadığı iktisadi açıdan ehemmiyet taşıyan bir sorudur. Bu bağlamda, araştırmada 
öğrencilerin İslami finans okuryazarlığının günümüzdeki İslami finans yöntemleri hakkındaki düşüncelerine ve finansal tercihlerine olan etkisi incelenmiştir.

Tablo 9. Banka Hesabının Bulunduğu Banka Türü

\begin{tabular}{|l|c|}
\hline Banka hesabınız varsa, bu hesap hangi tür bankada bulunuyor? & Öğrenci Yüzdesi (\%) \\
\hline - Bankada hesabım yok. & 16,2 \\
\hline - Katılım bankasında hesabım bulunuyor. & 11,7 \\
\hline - Klasik bankada hesabım bulunuyor. & 40,5 \\
\hline - Her ikisinde de hesabım bulunuyor. & 15,1 \\
\hline - Bilmiyorum. & 16,5 \\
\hline
\end{tabular}

Not: N=358. Tabloda her bir cevap seçeneği için öğrenci yüzdeleri verilmiştir.

Tablo 9'da görüleceği gibi araştırmadaki öğrencilerin, \%12'si sadece katıım ve \%15'i her iki tür bankada olmak üzere, toplam \%27'sinin katılım bankasında hesabı bulunmaktadır. Katılım bankası kullanan öğrencilere sebebi sorulduğunda, öğrencilerin \%51'i bu tercihlerinde dini sebeplerin önemli bir rolü olduğunu belirtmişlerdir. Bunun dışındaki bankanın yakınlığı, getirisi, hizmeti gibi unsurların tercihlerde sınırlı rol oynadığı anlaşılmaktadır. Öte yandan, öğrencilerin \%35'i katıım bankası kullanmasının belirli bir sebebi olmadığını söylemiştir.

İslami finans sisteminin geliştirilmesinin ana gayelerinden birinin, dini inançları gereği faizli olan güncel finansal sistemi kullanmayan (veya kullanmasına rağmen aslında kullanmak istemeyen) kişiler için uygun bir finans sistemi oluşturmak olduğu söylenebilir. Bu kiş̧ilerin, geliştirilen bu sistemi kullanmaları açısından sistemin İslam dinine uygun olduğunu düşünmesi önem taşımaktadır. Buradan yola çıkarak, ankette öğrencilere "Katılım bankalarının kullandığı finansal yöntemlerin İslami açıdan uygun olduğuna inanıyor musunuz?" sorusu yöneltilmiştir. Öğrencilerin sadece \%26'sı inandığını belirtirken, \%31'i inanamadığını ve \%43'ü bilmediğini söylemiştir. 
Tablo 10. İslam'a Uygunluk Düşüncesi

\begin{tabular}{|c|c|c|c|c|c|}
\hline & B & Standart Hata & Wald & $\operatorname{Exp}(B)$ & \\
\hline İslami Finans Okuryazarlığı & 0,306 & 0,084 & 13,392 & 1,357 & $\star \star \star$ \\
\hline Finansal Okuryazarlık & 0,070 & 0,088 & 0,632 & 1,072 & \\
\hline Cinsiyeti Erkek & $-0,345$ & 0,299 & 1,329 & 0,708 & \\
\hline Fakültesi IYYBF & 0,757 & 0,297 & 6,501 & 2,132 & $* * *$ \\
\hline Okuduğu Sınıf & $-0,351$ & 0,166 & 4,456 & 0,704 & ** \\
\hline Aile Eğitimi Üniversite & $-0,157$ & 0,290 & 0,294 & 0,855 & \\
\hline İşte Çalışmış / Çalışıyor & $-0,036$ & 0,294 & 0,015 & 0,965 & \\
\hline Düzenli Para Birikimi & $-0,075$ & 0,328 & 0,053 & 0,928 & \\
\hline Bankayla Alakalı & 0,486 & 0,422 & 1,327 & 1,626 & \\
\hline Para Konularına Meraklı & 0,328 & 0,394 & 0,693 & 1,388 & \\
\hline Omnibus Testi: $\chi^{2}=51,153(p=0,000)$ & \multicolumn{3}{|c|}{ Hosmer-Lemeshow Testi: $\chi^{2}=8,279(p=0,407)$} & \multicolumn{2}{|c|}{ Nagelkerke- $R^{2}=0,202$} \\
\hline
\end{tabular}

Not: N=344. Regresyonda bağımlı değişken öğrencinin katılım bankaları hakkındaki İslam'a uygunluk düşüncesi; bağımsız değişkenler İslami finans okuryazarlık düzeyi, finansal okuryazarlık düzeyi, cinsiyeti, fakültesi, sınıfı, aile eğitim seviyesi, çalışma durumu, finansal birikim düzeni, bankayla alakası ve para konularına merakıdır. Tablodaki *** , ** ${ }^{*}$ sırasıyla \%1, $\% 5$ ve $\% 10$ anlamllık seviyelerini göstermektedir.

İslami finans okuryazarlığının öğrencilerin günümüz İslami finans yöntemleri hakkındaki düşünceleri üzerine etkisi olup olmadığını incelemek amacıyla ikili lojistik regresyon analizi yapılmıştır. Bu regresyonda bağımlı değişken, katılım bankalarının kullandıkları yöntemlerin İslam'a uygun olduğuna inananların 1 ve diğerlerinin 0 değerini aldığı bir kukla değişkendir. Bağımsız değişkenler, İslami finans okuryazarlık ve finansal okuryazarlık düzeylerinin yanı sıra öğrencinin demografik özellikleri ve finans sistemiyle ilişkili bilgilerinden oluşmaktadır. Tablo 10' daki regresyon sonuçlarına göre, finansal okuryazarlık düzeyinin anlamlı bir etkisi bulunmazken, İslami finans okuryazarlık düzeyi İslam'a uygunluk düşüncesini \%1 anlamlılık seviyesinde pozitif olarak etkilemektedir.

Tablo 11. Yeni Hesap Açmayı Düşündüğü Banka Türü

\begin{tabular}{|l|c|}
\hline Yeni bir banka hesabı açacak olsanız, hangi tür bankada hesap açardınız? & $\begin{array}{c}\text { Öğrenci } \\
\text { Yüzdesi (\%) }\end{array}$ \\
\hline - Katıım bankasında hesap açardım. & 31,5 \\
\hline - Klasik bankada hesap açardım. & 17,8 \\
\hline - Farketmez. & 18,9 \\
\hline - Bankada hesap açmam. & 7,0 \\
\hline - Bilmiyorum. & 24,8 \\
\hline
\end{tabular}

Not: N=359. Tabloda her bir cevap seçeneği için öğrenci yüzdeleri verilmiştir. 
İslami finans okuryazarlık düzeyindeki artışın İslami finans sisteminin gelişmesinde ve yaygınlaşmasında katkısı olup olmadığını incelemek amacıyla öğrencilere yeni hesap açmak istediklerinde hangi banka türünü tercih edecekleri sorulmuştur. Tablo 11 'de görüleceği üzere, öğrencilerin \%32'si katılım bankasını ve \%18'i ise klasik bankayı tercih etmiştir. Bu bilgi kullanılarak, yeni banka hesabı açacağında katılım bankasını tercih edeceğini söyleyenlerin 1 ve diğerlerinin 0 değerini aldığı bir kukla değişken üretilerek ikili lojistik regresyon analizi yapılmışır. Burada bağımsız değişkenler olarak, İslami finans okuryazarlık düzeyiyle birlikte İslam'a uygunluk düşüncesi, finansal okuryazarlık düzeyi, öğrencinin demografik özellikleri ve finans sistemiyle ilişkili bilgileri yer almaktadır. Regresyon analizi sonuçları Tablo 12'de sunulmuştur.

\section{Tablo 12. Finansal Tercih}

\begin{tabular}{|c|c|c|c|c|c|}
\hline & B & $\begin{array}{c}\text { Standart } \\
\text { Hata }\end{array}$ & Wald & $\operatorname{Exp}(B)$ & \\
\hline İslami Finans Okuryazarlığı & 0,235 & 0,082 & 8,228 & 1,265 & $* * *$ \\
\hline İslam’a Uygun Düşüncesi & 1,168 & 0,285 & 16,806 & 3,217 & $* * *$ \\
\hline Finansal Okuryazarlık & 0,106 & 0,083 & 1,661 & 1,112 & \\
\hline Cinsiyeti Erkek & $-0,127$ & 0,292 & 0,190 & 0,881 & \\
\hline Fakültesi iYBF & 0,638 & 0,293 & 4,747 & 1,892 & ** \\
\hline Okuduğu Sınıf & 0,181 & 0,147 & 1,517 & 1,199 & \\
\hline Aile Eğitimi Üniversite & 0,358 & 0,275 & 1,691 & 1,430 & \\
\hline İşte Çalışmış / Çalışıyor & 0,016 & 0,287 & 0,003 & 1,016 & \\
\hline Düzenli Para Birikimi & $-0,098$ & 0,317 & 0,096 & 0,907 & \\
\hline Para Konularına Meraklı & $-0,269$ & 0,358 & 0,565 & 0,764 & \\
\hline Omnibus Testi: $\chi^{2}=64,652(p=0,000)$ & \multicolumn{3}{|c|}{ Hosmer-Lemeshow T.: $\chi^{2}=13,374(p=0,100)$} & \multicolumn{2}{|c|}{ Nagelkerke- $R^{2}=0,242$} \\
\hline
\end{tabular}

Not: N=342. Regresyonda bağımlı değişken öğrencinin yeni banka hesabı için katııım bankasını tercih etmesi; bağımsız değişkenler öğrencinin İslami finans okuryazarlık düzeyi, katılım bankaları hakkındaki İslam'a uygunluk düşüncesi, finansal okuryazarlık düzeyi, cinsiyeti, fakültesi, sınıfı, aile eğitim seviyesi, çalışma durumu, finansal birikim düzeni, bankayla alakası ve para konularına merakıdır. Tabloda ***, **, * sırasıyla \%1, \%5 ve \%10 anlamlılık seviyelerini göstermektedir.

Tablo 12'deki sonuçlara göre, diğer değişkenler sabit tutulduğunda, öğrencinin İslami finans okuryazarlık düzeyinin ve katılım bankalarının İslam'a uygun olduğunu düşünmesinin yeni bir banka hesabı açarken katılım bankalarını tercih etmesine pozitif olarak \%1 anlamlılık seviyesinde etki ettiği görülmektedir. Finansal okuryazarlık düzeyinin ise, bekleneceği üzere, katılım bankalarını tercih etmede anlamlı bir etkisi bulunmamaktadır. 
Sonuç olarak, İslami finans okuryazarlık düzeyi artışının öğrencilerin katıım bankasında kullanılan yöntemlerin İslam'a uygun olduğunu düşünme ihtimalini artırdığı; bununla birlikte hem İslami finans okuryazarlığı artışının hem de İslam'a uygunluk düşüncesinin öğrencilerin finansal davranışlarını etkilediği ve katıım bankasını bilinçli olarak tercih etmeleri konusunda katkısı olduğu görülmektedir. ${ }^{13}$ Böylece, toplumda İslami finans okuryazarlık seviyesinin yükselmesinin İslami finans sisteminin yaygınlaşmasında olumlu etkisi olacağını söylenebilir.

\section{Sonuç ve Öneriler}

Bu araştırma, Türkiye'deki İslami finans okuryazarlık düzeyini üniversite öğrencileri üzerinden inceleyerek, finansal okuryazarlık düzeyi ile ilişkisini ve henüz gelişme aşamasında olan İslami finansın yaygınlaşması hususundaki katkısını analiz etmeyi amaçlamıştır.

Araştırma kapsamında yapılan anket sonucunda, üniversite öğrencilerinin İslami finans okuryazarlık düzeyinin oldukça düşük olduğu; hatta pek çoğunun İslami finans farkındalığına sahip olmadığı görülmüştür. İslami finans okuryazarlık düzeyi doğrusal regresyon yöntemiyle analiz edildiğinde, diğer değişkenler sabitken, erkek öğrencilerin, İşletme ve Yönetim Bilimleri Fakültesinde öğrenim görenlerin ve üst sınıflarda okuyanların ortalama düzeyinin daha yüksek olduğu tespit edilmiştir. Öğrencinin parayla ilgili konularda meraklı olmasının ve banka hesabı, kredi kartı veya internet bankacılığı kullanmasının da ortalama düzeyi yükselttiği anlaşılmıştır. Ayrıca, öğrencinin demografik özellikleri ve finansal hayatla ilişkilerine dair değişkenler sabit tutulduğunda, finansal okuryazarlık düzeyindeki artış ile birlikte İslami finans okuryazarlık düzeyinin anlamlı olarak arttığı belirlenmiştir.

İslam finans ve İslami ilimler eğitiminin etkisi doğrusal regresyon ile analiz edilmiştir. İslam Ekonomisi ve Finans bölümünde öğrenim görmenin İslami finans okuryazarlık seviyesini önemli ölçüde artırdığı görülmüş; İslami illimler bölümünde öğrenim görmenin ise anlamlı bir etkisi bulunamamıştır.

İslami finans sisteminin yayılmasında, İslami finans okuryazarlık düzeyinin bir katkısı olup olmadığını incelemek için ikili lojistik regresyon analizi yapılmıştır. Analiz sonuçları, bu düzeyin artışının, öğrencinin katılım bankalarının kullandığı yöntemlerin İslam'a uygunluğuna olan inancını olumlu olarak etkilediğini göstermektedir. Bunun

13 Bu ikili lojistik regresyon analizi, bağımlı değişken "yeni hesap açarken katııım bankasını tercih etmek" yerine "katııım bankasında hesabı bulunmak" ya da "sadece katıım bankasında hesabı bulunmak" olacak şekilde tekrar yapıldığında, ne İslami finans okuryazarlık düzeyi için ne de İslam'a uygunluk düşüncesi için anlamlı bir ilişki bulunamamıştır. Buradan, İslami finans okuryazarlık düzeyindeki artışın katıım bankasını bilinçli tercih etmede olumlu bir etkisi olduğu sonucuna varılabilir. 
yanı sıra hem İslam'a uygunluk düşüncesinin hem de İslami finans okuryazarlığının öğrencinin yeni bir banka hesabı açacağı zaman katılım bankasını tercih etme intimalini artırdığı tespit edilmiştir.

Son dönemde devletin, kamu adına faaliyet gösteren katıım bankaları kurarak, bireysel emeklilikte faizsiz sistem alternatifi sunarak, kamu sukuk ihracı yaparak, üniversitelerde İslam ekonomisi ve finansı bölümlerine onay vererek İslami finansın gelişmesine ve yaygınlaşmasına ortam sağladığı ve destek olduğu görülmektedir. Katılım bankaları da hizmet kalitesini artırarak ve ürün çeşitliliğini çoğaltarak finans sistemi içindeki payını büyütmeye çalışmaktadırlar. Buna rağmen, Türkiye'de İslami finansın bilinirliği ve güncel finansal sistem içerisindeki payı hâlâ oldukça sınırlı bir gelişme göstermektedir.

Yapılan çalışmalar gösteriyor ki, Türkiye'de İslami finans farkındalığı ve okuryazarlı̆̆ı oldukça düşük seviyededir (Er, Mutlu, v.d., 2015; Çömlekçi, 2017; Durmuş ve Yardımcıoğlu, 2018). Bu araştırma ile birlikte de katılım bankası ile klasik bankanın farkını pek çok kişinin bilmediği; İslami finans sisteminin faizsiz olması, katılım bankalarının hesap sahiplerine kâr payı vermesi ve faaliyetlerinin kâr-zarar ortaklığı esasına dayanması gibi temel bilgilerin bile genel anlamda eksik olduğu anlaşılmaktadır.

Bu araştırmadan yola çıkarak, Türkiye'de İslami finans farkındalığı ve okuryazarlığının artııımasının Türkiye'deki İslami finans sektörünün gelişmesine ve yaygınlaşmasına olumlu etki edeceği söylenebilir. Bu doğrultuda, finansal okuryazarlık konusunda olduğu gibi, İslami finans okuryazarlığıyla ilgili de çalışmalar yapılmasının gerekli olduğu görülmektedir. İslami finans konusunda bireylerin bilinçlendirilmesi ve bilgilendirilmesinin önemli olduğu ve İslami finans eğitimlerinin düzenlenmesinin faydalı olacağı anlaşılmaktadır. Ayrıca, uzman kişilerin yetiştirilmesi bakımından üniversitelerde İslam ekonomisi ve İslami finans alanlarında lisans ve lisansüstü programların artııımasının yanı sıra i̇slami ilimler programlarına da ekonomi ve finansla ilgili dersler eklenmesinin Türkiye'de İslami finans alanının gelişebilmesi açısından yararlı olacağı görülmektedir. 


\section{Kaynakça}

1. Abdullah, M. A. ve Chong, R. (2014). Financial Literacy: An Exploratory Review of the Literature and Future Research. Journal of Emerging Economies and Islamic Research, 2(3): 1-9.

2. Abdullah, M. A., Wahab, S. N. A., Sabar, S. ve Abud, F. (2017). Factors determining Islamic financial literacy among undergraduates. Journal of Emerging Economies \& Islamic Research, 5(2): 67-76.

3. Alkaya, A. ve Yağlı, İ. (2015). Finansal Okuryazarlık-Finansal Bilgi, Davranış ve Tutum: Nevşehir Hacı Bektaş Veli Üniversitesi iỉBF Öğrencileri Üzerine Bir Uygulama. Uluslararası Sosyal Araştırmalar Dergisi, 8(40): 585-599.

4. Antara, P., Musa, R. ve Hassan, F. (2016). Bridging Islamic Financial Literacy and Halal Literacy: The Way Forward in Halal Ecosystem. Procedia Economics and Finance, 37: 196-202.

5. Baysa, E. ve Karaca, S. S. (2016). Finansal Okuryazarlık ve Banka Müşteri Segmentasyonları Üzerine Bir Uygulama. Muhasebe ve Finansman Dergisi, (71): 109-125.

6. Beal, D. J. ve Delpachitra, S. B. (2003). Financial Literacy among Australian University Students. Economic Papers, 22(1): 65-78.

7. Berekeci, N. E., Ayrıçay, Y. ve Kök D. (2018). İslami Finansal Okuryazarlık: Kahramanmaraş Sütçü Imam Üniversitesi'nde Bir Alan Araştırması. Pamukkale Üniversitesi Sosyal Bilimler Enstitüsü Dergisi, 33: 45-60.

8. Bernheim, B. D. ve Garrett, D. M. (2003). The Effect of Financial Education in the Workplace: Evidence from a Survey of Households. Journal of Public Economics, 87(7-8): 1487-1519.

9. Bianchi, M. (2018). Financial Literacy and Portfolio Dynamics. The Journal of Finance, 73(2): 831-859.

10. Bowen, C. F. (2002). Financial Knowledge of Teens and Their Parents. Financial Counseling and Planning, 13(2): 93-102.

11. Brent, D.A. ve Ward, M.B. (2018). Energy Efficiency and Financial Literacy. Journal of Environmental Economics and Management, 90: 181-216. 
12. Chen, H. ve Volpe, R.P. (2002). Gender Differences in Personal Financial Literacy among College Students. Financial Services Review, 11(3): 289-307.

13. COMCEC, (2017) Diversification of Islamic Financial Instruments. http:// ebook.comcec.org/ Kutuphane/Icerik/Yayinlar/Analitik_Calismalar/Mali_ Isbirligi/Toplanti9/files/assets/common/downloads/publication.pdf, Erişim Tarihi: 24/10/2018.

14. Coşkun, S. (2016). Üniversite Öğrencilerinin Finansal Davranış ve Tutumlarının Belirlenmesi: Finansal Okuryazarlık Algıları Üzerine Bir Araştırma. İnsan ve Toplum Bilimleri Araştırmaları Dergisi, 5(7): 2247-2258.

15. Çam, A. ve Barut, A. (2015). Finansal Okuryazarlık Düzeyi ve Davranışları: Gümüşhane Üniversitesi Önlisans Öğrencileri Üzerinde Bir Araştırma. Global Journal of Economics and Business Studies, 4(7): 63-72.

16. Çömlekçi, i. (2017). İslami Finansal Okuryazarlık Düzeyinin Belirlenmesi: Katılım Bankaları Müşterileri Üzerine Araştırma. Elektronik Sosyal Bilimler Dergisi, 16(63): 1423-1439.

17. Durmuş, M. E. ve Yardımcıoğlu, F. (2018). İlahiyat Öğrencileri Ne Kadar İslami Finans Okuryazarı?" Siyaset, Ekonomi ve Yönetim Araştırmaları Dergisi, 6(1): 167-183.

18. Er, B., Mutlu, M. ve Şahin, Y. E. (2015, Ekim). Daha Bilgili, Daha Doğru: İslami Finans Okuryazarlığı Üzerine Bir Araştırma. International Congress on Islamic Economics and Finance (ICISEF) 2015 Proceedings Volume II, 1-22.

19. Er, B. ve Mutlu, M. (2017). Financial Inclusion and Islamic Finance: A Survey of Islamic Financial Literacy Index. International Journal of Islamic Economics and Finance Studies, 3(2): 33-54.

20. Ergün, B., Şahin, A. ve Ergin, E. (2014). Finansal Okuryazarlık: İşletme Bölümü Öğrencileri Üzerine Bir Çalışma. Uluslararası Sosyal Araştırmalar Dergisi, 7(34): 847-64.

21. Finke, M. S., Howe, J. S. ve Huston, S. J. (2016). Old Age and the Decline in Financial Literacy. Management Science, 63(1): 213-230.

22. Fox, J. J., Bartholomae, S. ve Lee, J. (2005). Building the Case for Financial Education. Journal of Consumer Affairs, 39: 195-214. 
23. Gutnu, M. M. ve Cihangir, M. (2015). Finansal Okuryazarlık: Osmaniye Korkut Ata Üniversitesi Personeli Üzerinde Bir Araştırma. Akademik Sosyal Araştırmalar Dergisi, 10(3): 414-424.

24. Hidajat, T. ve Hamdani, M. (2017), Measuring Islamic Financial Literacy. Advanced Science Letters, 23(8): 7173-7176.

25. İstanbul Sabahattin Zaim Üniversitesi (ISZU), (2017) Yükseköğretim Kalite Kurulu Kurumsal Geri Bildirim Raporu (21/01/2017).

26. Kılıç, Y., Ata, H. A. ve Seyrek, I. H. (2015). Finansal Okuryazarlık: Üniversite Öğrencilerine Yönelik Bir Araştırma, Muhasebe ve Finansman Dergisi, (66): 129-150.

27. Kocabıyık, T. Ve Teker, T. (2018). Finansal Okuryazarlık: Süleyman Demirel Üniversitesi Öğrencileri Üzerine Bir Araştırma. Stratejik ve Sosyal Araştırmalar Dergisi, 2(2): 117-144.

28. Lusardi, A. ve Mitchell, O. S. (2007). Financial Literacy and Retirement Preparedness: Evidence and Implications for Financial Education. Business Economics, 42(1): 35-44.

29. Lusardi, A. ve Mitchell, O. S. (2008). Planning and Financial Literacy: How Do Women Fare? American Economic Review, 98(2): 413-417.

30. Lusardi, A. ve Mitchell, O. S. (2015). The Economic Importance of Financial Literacy: Theory and Evidence, Journal of Economic Literature, 52(1): 5-44.

31. Mandell, L. (2008). Financial Literacy of High School Students. In J. J. Xiao (Ed.), Financial Literacy of High School Students. New York: Springer.

32. OECD/INFE. (2011). Measuring Financial Literacy: Core Questionnaire in Measuring Financial Literacy: Questionnaire and Guidance Notes for conducting an Internationally. Paris: OECD.

33. OECD/INFE. (2016). OECD/INFE International Survey of Adult Financial Literacy Competencies. Paris: OECD.

34. Özdemir, M. ve Aslan, H. (2017). Türkiye'de İslami Finansın Dönüşümünün Ekonomi Politiği. İstanbul: SETA.

35. Öztürk, E. ve Demir, Y. (2015). Finansal Okuryazarlık ve Para Yönetimi: 
Süleyman Demirel Üniversitesi Akademik Personel Üzerine Bir Uygulama. Muhasebe ve Finansman Dergisi, (68): 113-134.

36. Rahim, S. H., Rashid, R. A. ve Hamed, A. B. (2016). Islamic Financial Literacy and its Determinants among University Students: An Explanatory Factor Analysis. International Journal of Economics and Financial Issues, 6(S7): 3235.

37. Rammal, H. G. ve Zurbruegg, R. (2016). Awareness of Islamic Banking Products among Muslims: The Case of Australia. In T. Harrison ve E. Ibrahim (Ed.), Islamic Finance. Cham: Palgrave Macmillan.

38. Rasoaisi, L. ve Kalebe, K. (2015). Determinants of Financial Literacy among the National University of Lesotho Students. Asian Economic and Financial Review, 5(9): 1050-1060.

39. Servon, L. J. ve Kaestner, R. (2008). Consumer Financial Literacy and the Impact of Online Banking on the Financial Behavior of Lower-Income Bank Customers. Journal of Consumer Affairs, 42: 271-305.

40. Şahin, M. ve Barış, S. (2017). Finansal Okuryazarlık ve Tasarruf Davranışları: Kamu Çalışanları Üzerine Bir İnceleme. Çankırı Karatekin Üniversitesi IïBF Dergisi, 7(2): 77-103.

41. Şamiloğlu, F., Kahraman, Y. E. ve Bağcı, H. (2016). Finansal Okuryazarlık Araştırması: Erciyes Üniversitesi Öğrencileri Üzerinde Bir Uygulama. Uluslararası Yönetim İktisat ve İşletme Dergisi, 16: 308-318.

42. Türkiye Cumhuriyet Merkez Bankası (TCMB), (2015) TCMB Bülten Mart 2015 Sayı 37, www.tcmb.gov.tr.

43. Türkiye Cumhuriyet Merkez Bankası (TCMB), Finansal Okuryazarlık ve Ekonomi Eğitimi, www.tcmb.gov.tr/wps/wcm/connect/TR/TCMB+TR/Main+Menu/ Banka+Hakkinda/Egitim-Akademik/Finansal+Okuryazarlik, Erişim Tarihi: $14 / 3 / 2019$.

44. Türkiye Katılım Bankaları Birliği (TKBB), Mukayeseli Tablolar, www.tkbb.org. tr/mukayeseli-tablolar, Erişim Tarihi: 11/07/2019.

45. van Rooij, M., Lusardi, A. ve Alessie, R. (2011). Financial Literacy and Stock Market Participation. Journal of Financial Economics, 101(2): 449-472. 
46. Volpe, R. P., Chen, H. ve Pavlicko., J.J. (1996). Personal Investment Literacy among College Students: A Survey. Financial Practice and Education, 6(2): 86-94.

47. Yazıcıoğlu, Y. ve Erdoğan, S. (2004). SPSS Uygulamalı Bilimsel Araştırma Yöntemleri. Ankara: Detay Yayınclık. 